\title{
OF FREE TRADE AGREEMENTS AND MODELS
}

\author{
C. O’Neal Taylor
}

\section{INTRODUCTION}

In the last two decades, the United States has altered its focus in trade policy. This alteration sprang from the United States' attempts to mesh its long-held commitment to multilateralism with regionalism. ${ }^{1}$ During the postWorld War II negotiations for the General Agreement on Tariffs and Trade (GATT), ${ }^{2}$ the United States championed non-discrimination as the major trading principle and sought to dismantle preferential trading relationships. ${ }^{3}$ Even though the GATT, as negotiated, contained an exception to the MostFavored-Nation (MFN) principle to allow Contracting States to form both customs unions and free trade areas, ${ }^{4}$ the United States did not take advantage of it until the mid-1980s. The United States entered into two free trade

* Professor of Law, South Texas College of Law, A.B. Harvard-Radcliffe, J.D. University of Georgia, LL.M. Georgetown University Law Center. The author would like to thank the editorial board of the Indiana International and Comparative Law Review for the invitation to speak at the symposium and its assistance with this article. The author would also like to thank Associate Dean Catherine G. Burnett for her insights and help. Finally, the author would like to recognize the research assistance offered by Adnan Sarwar and Justin Jenson (J.D. South Texas College of Law, 2008 \& 2009).

1. See Jagdish Bhagwati, Regionalism and Multilateralism: An Overview 29, in New DimENSIONS IN REgIONALISM INTEGRATION (Jaime deMelo \& Arvind Panagriya eds., Cambridge Univ. Press 1993).

According to Bhagwati, the U.S. shift towards regionalism was a pivotal factor in the worldwide shape of the phenomenon. "The main driving force for regionalism toady is the conversion of the United States, hereto an abstaining party, to [GATT] Article XXIV ... [T] he conversion of the United States is of major significance. As the key defender of multilateralism through the postwar years, its decisions now to travel the regional route (in the geographical and preferential senses simultaneously) tilts the balance of forces at the margin away from multilateralism to regionalism." Id.

2. General Agreement on Tariffs and Trade, Oct. 30, 1947, 61 Stat. A-11, T.I.A.S. No. 1700, 55 U.N.T.S. 194 [hereinafter GATT], available at http://www.wto.org/english/docs_e/ legal_e/gatt47_e.pdf.

3. The United States wanted to take apart the trading preferences, particularly the Commonwealth system operated by Great Britain. Central to such an effort was establishing the Most-Favored Nation (MFN) principle as the core GATT obligation. An unconditional MFN rule would require that any benefit or privilege granted to one trading partner must be offered to others. See KENNETH W. DAM, THE GATT: LAW AND INTERNATIONAL ECONOMIC ORGANIZATION 27 (Univ. of Chicago Press 1977) (1970); JOHN H. JACKSON, WORLD TRADE LAW AND THE LAW OF THE GATT 577 (The Bobbs-Merrill Company, Inc. 1969); JACOB VINER, THE Customs UNION ISSUE 110 (Camegie Endowment 1950).

4. GATT, supra note 2 , at art. XXIV. 
agreements in that decade. The first, with Israel, ${ }^{5}$ was entered into for foreign policy reasons in order to support an ally. The second, with Canada, ${ }^{6}$ was a formal recognition of the already closely integrated economies of the two countries. It was the third U.S. free trade agreement, the North American Free Trade Agreement (NAFTA), ${ }^{7}$ that marked the shift in U.S. trade policy towards one of multilateralism plus regionalism.

Several factors contributed to this conversion of the United States on the issue of pursuing regionalism as part of its standard trade policy. Almost all of these were related to the U.S. experience with globalization and the multilateral system rather than to any particular belief in the value or efficacy of regionalism. First, during the 1980s, the United States saw the first significant decline in living standards and wages in the post-war period. ${ }^{8}$ Perceiving itself as a "diminished giant," "9 the United States came to view the GATT system as one in which it gave much while other countries, such as Japan and the developing countries, ${ }^{10}$ gave little. Second, the U.S. method of response to the inadequacies of the GATT rules ${ }^{11}$ and its dispute settlement system ${ }^{12}$ was to engage in aggressive unilateralism to push its own agenda in the latest round of GATT negotiations, the Uruguay Round. The United States satisfied its goals

5. U.S.-Israel Free Trade Agreement, U.S.-Isr., Apr. 22, 1985, 24 I.L.M. 653 [hereinafter U.S.-Israel FTA], available at http://tcc.export.gov/Trade_Agreements/All_Trade_Agreements/ exp_005439.asp.

6. U.S.-Canada Free Trade Agreement, U.S.-Can., Jan. 2, 1988, 27 I.L.M. 281 [hereinafter U.S.-Canada FTA], available at $\mathrm{http}: / /$ wehner.tamu.edu/mgmt.www/NAFTA/fta/complete.pdf.

7. North American Free Trade Agreement, U.S.-Can.-Mex., Dec. 17, 1992, 32 I.L.M. 289 (containing chs. 1-9), 32 I.L.M. 605 (containing chs. 10-22) [hereinafter NAFTA], available at http://www.nafta-sec-alena.org/DefaultSite/index_e.aspx?DetailID=78.

8. See Jagdish Bhagwati, The Diminished Giant Syndrome: How Declinism Drives Trade Policy, 72 FOREIGN AFF. 22, 22 (1992-93) [hereinafter Bhagwati]; JAGDISH BHAGWATI, THE WORLD TRADING SYSTEM AT RISK 15-16 (Harvester Wheatsheaf 1991).

9. Bhagwati, supra, note 8 at 22-26 (comparing the United States to Great Britain, the other diminished giant faced with competition from the United States and Germany).

10. Id. at 22-24 (noting the United States's belief that the GATT system had provided asymmetrical benefits to the world trading system and that the Japanese economy was a "closed" one as compared to the United States). The developing countries were seen as problems because they failed to offer adequate standards of protection for intellectual property rights or openings for trade in services. See generally C. O'Neal Taylor, The Limits of Economic Power: Section 301 and the World Trade Organization Dispute Settlement System, 30 VAND. J. TRANSNAT'L L. 209, 214-225 (1997) (noting the U.S. dissatisfaction with developing countries over these issues and its use of Section 301 with its power to sanction trading partners to force changes by them).

11. The United States believed the GATT regime was inadequate in part because it failed to offer discipline over trade in services and rules on intellectual property rights protection. Taylor, supra note 10, at 220-237.

12. The GATT Article XXIII dispute settlement system required GATT adoption of any panel decision and allowed the losing party to block the adoption of the report. The United States was so concerned about the inadequacies of the GATT system that it pushed for adoption of a new dispute settlement system during the Uruguay Round. For a thorough review of the U.S. position on this issue, see id. at $242-250$. 
of adding trade and services and trade-related intellectual property rights to those negotiations. However, an impasse developed over one major area of trade - agriculture - that had to be brought under GATT discipline for the round to complete. When the European Community (EC) refused to negotiate on dismantling its barriers at a level that was considered satisfactory, the United States walked out of the negotiations. It was during this break in negotiations that the United States signaled its intent to achieve at a regional level what was being forestalled at the GATT. ${ }^{13}$ After obtaining "fast-track" negotiating authority in $1991,{ }^{14}$ the Bush Administration began negotiating for NAFTA and made those negotiations its focus for the next few years. By 1992, the United States, Canada and Mexico had signed the free trade agreement. In 1993, the side agreements on labor rights and environmental cooperation were completed ${ }^{15}$ and NAFTA entered into force the following year. The shift away from multilateralism towards regionalism by the United States helped to spark a renewed enthusiasm for the Uruguay Round negotiations, which were completed at the end of $1994 .^{16}$

It is fair to characterize the initial U.S. foray into regionalism as a strategy designed: (1) to compel the EC to return to negotiations on agriculture and complete the Uruguay Round; and (2) to offer NAFTA as a model of what could be negotiated on new trade rules (including, most importantly, trade in

13. See Gilbert R. Winham, The Evolution of International Trade Agreements 8692 (Univ. of Toronto Press 1992) (discussing the impasse at the Uruguay Round negotiations which resulted in a suspension of the negotiations in December 1990); see also Joint Statement Announcing Canada-Mexico-United States Trilateral Free Trade Negotiations (Feb. 5, 1991), 1991 PUB. PAPERS 111, available at http://www.presidency.ucsb.edu/ws/?pid=19279.

14. Congress shares trade making authority with the President under the Constitution. U.S. Const. art. 1, 8 cls. 1,3 (Congress has power to "lay and collect Taxes, Duties, Imposts and Excises" and to "regulate commerce with foreign nations."). Any trade agreement negotiated by the President must be approved by Congress. President Bush had to request fast track authority to negotiate NAFTA. The effort to get fast track was complicated by Congressional distrust of the Executive. C. O'Neal Taylor, Fast Track, Trade Policy and Free Trade Agreements: Why The NAFTA Turned Into A Battle, 28 GW J. INT'L L. \& ECON. 2, 36-50.

15. Bill Clinton campaigned against President Bush's NAFTA and promised to negotiate the labor and environmental side agreements. When he won the 1992 election, Clinton followed through with this pledge. For a short history of the final completion of NAFTA, see id. at 4-10.

16. The completion of the Uruguay Round of negotiations resulted in the creation of the World Trade Organization (WTO) and the adoption of an expanded list of agreements that each Member State was required to adopt. Given the United States' agenda and its use of aggressive unilateralism to start the Uruguay Round, the most important of these agreements were the General Agreement on Trade in Services, The Agreement on Trade-Related Intellectual Property Rights, and the Dispute Settlement Understanding. General Agreement on Trade in Services, Jan. 1, 1995, Marrakesh Agreement Establishing the World Trade Organization, Final Act Embodying the Results of the Uruguay Round of Multilateral Trade Negotiations, GATT Doc. MTN/FA, Annex 1B, available at http://www.wto.org/english/docs_e/legal_e/26-gats.pdf [hereinafter GATS]; Agreement on Trade-Related Aspects of Intellectual Property Rights, Apr. 15, 1994, Marrakesh Agreement Establishing the World Trade Organization, 33 I.L.M. 1125 1226 (1994), available at http://www.wto.org/english/tratop_e/trips_e/t_agm0_e.htm [hereinafter TRIPs]. 
services and trade-related intellectual property rights). It was not clear at the time that the United States would become a proponent of regionalism in order to continue pushing the U.S trade agenda. What has happened since, however, suggests otherwise. The United States has been engaged in free trade negotiations with groups or individual countries since $1994,{ }^{17}$ even as it participated actively in the new World Trade Organization (WTO) and its latest round of negotiations, the Doha Round. ${ }^{18}$ From 2001 to 2008 , the United States entered into nine free trade agreements (FTAs), ${ }^{19}$ and completed and signed three more FTA ${ }^{20}$ and several ongoing initiatives ${ }^{21}$ aimed at producing more bilateral FTAs. Why has the United States come to embrace this shift to multilateralism plus regionalism? To answer that question fully, it is necessary to examine the contours and content of U.S. regionalism. This Article will do that by examining and analyzing (1) how the United States has developed its model for FTAs, and (2) the implications of the United States' decision to

17. The first set of negotiations was convened to create a Free Trade of the Americas (FTAA). The goal of the Free Trade of the Americas initiative was to create a free trade area uniting all of the 34 democracies of the Western Hemisphere. The negotiating process produced eight ministerial meetings (between 1995-2003), four Summits of the Americas (1994, 1998, 2001 and 2005) and draft texts before it was suspended. According to the United States, that was because "other leaders indicated that conditions did not exist for the achievement of the FTAA.” WTO, Trade Policy Review, Report by United States, WT/TPR/G200, at 14 (2008) [hereinafter US/TPR], available at www.wto.org/english/tratop_e/tpr_e/g200_e.doc.

For a review of the issues that led to the suspension of the FTAA, see David A. Gantz, The Free Trade Area of the Americas: An Idea Whose Time Has Come-and Gone?, 1 LoY. INT'L L. REv. 179 (2004). For official materials on the FTAA, see the United States Trade Representative webpage, http://www.ustr.gov/Trade_Agreements/Regional/FTAA/Section Index.html.

18. The Doha Round was launched in 2001 and was focused, for the first time in GATT/WTO history, on issues of concern to the majority of WTO Member States-the developing countries.

19. The most recent U.S. free trade agreements (FTAs) are those negotiated or enacted under the Bush Administration. The following represents a chronological list of the agreements and their enactment in the United States as of 2008: U.S.-Jordan (2001); U.S.-Singapore (2003); U.S.-Chile (2003); U.S.-Australia (2004); U.S.-Morocco (2004); U.S.-CAFTA-DR (2005); U.S.-Bahrain (2006); U.S.-Oman (2006); U.S.-Peru (2007). See UNITED STATES TRADE Representative (USTR), The President's 2008 Trade Policy Agenda 107-15 (2008), available at http://www.ustr.gov/assets/Document_Library/Reports_Publications/2008/ 2008_Trade_Policy_Agenda/asset_upload_file649_14563.pdf.

20. The signed FTAs pending Congressional approval are with Panama, Colombia and South Korea. See U.S.-Panama Free Trade Agreement, U.S.-Pan., Jun. 28, 2007, available at http://www.ustr.gov/Trade_Agreements/Bilateral/Panama_FTA/Final_Text/Section_Index.html [hereinafter U.S.-Panama FTA]; U.S.-Colombia Trade Promotion Āgreement, U.S.-Colom., Nov. 22, 2006, available at http:/www.ustr.gov/Trade_Agreements/Bilateral/Colombia_FTA /Final_Text/Section_Index.html [hereinafter U.S.-Colombia FTA]; U.S.-Korea Free Trade Agreement, U.S.-Kor., Jun. 30, 2007, available at http://www.ustr.gov/Trade_Agreements/ Bilateral/Republic_of_Korea_FTA/Final_Text/Section_Index.html [hereinafter KORUS].

21. The regional initiatives, all launched in 2002-2003, were with the South African Customs Union (SACU), the Enterprise for ASEAN Initiative (EAI), the CAFTA Initiative, and the Middle East Free Trade Area Initiative (MEFTAI). See generally US/TPR, supra note 17, at 15-16. 
embrace this model-based approach to regionalism for the United States, its FTA partners, and the world trading system.

\section{A SHORT HISTORY OF U.S. POST-NAFTA REGIONALISM}

Following the enactment of NAFTA in 1994, the United States committed itself to negotiating a Free Trade Agreement of the Americas (FTAA). Since the FTAA was by nature and intent aimed at achieving comprehensive regionalism for the Western Hemisphere, the thirty-four negotiating countries set up a long time-table for negotiating the completion of the free trade area by $2005 .^{22}$ During the remainder of the Clinton Administration (1994-2000), the United States made only limited efforts to pursue bilateral free trade agreements due to a lack of political consensus on such agreements, the fallout from NAFTA, ${ }^{23}$ and the expiration of fast track authority and congressional unwillingness to renew this authority. ${ }^{24}$ The Clinton Administration did begin negotiations with some countries that approached fast track authority (Jordan, Chile, and Singapore). ${ }^{25}$ However, it only did so after becoming concerned about the burgeoning of the FTA movement worldwide ${ }^{26}$ and another slowdown in multilateral negotiations at the WTO. ${ }^{27}$ The Clinton Administration completed one free trade agreement with Jordan, which was enacted in 2001 during the Bush Administration. ${ }^{28}$

Under President G. W. Bush, the United States has extended the developing system for negotiating and enacting regional arrangements. President Bush had a singular advantage denied President Clinton: early in his

22. See generally DILIP K. DAS, Regionalism in the Western Hemisphere in REGIONALISM IN GLoBal Trade 192-199 (2004) (discussing the plan behind the FTAA, its time frame and its goal to go beyond the WTO in legal rules).

23. Susan G. Esserman, Proceeding of the Canada-United States Law Institute Conference on Understanding Each Other Across the Largest Undefended Border in History, 31 CAN.-U.S. L. J. 11, 14 (2005) (noting these as the reasons why the United States did not pursue bilateral FTAs).

24. The Clinton Administration was without fast track authority from April 16, 1994 until its end in 2000. Congress did not pass a trade negotiating authorization until 2002.

25. Esserman, supra note 23, at 14.

26. Id. Following NAFTA, Mexico and Canada began to negotiate FTAs with Chile. These agreements were explicitly modeled after NAFTA. See DAS, supra note 22, at 181 ("T] $]$ he Chile-Mexico and Chile-Canada agreements were based exactly on the innovative NAFTA model, as were the new bilateral FTAs between Chile and Mexico on the one side and countries throughout Latin America on the other."). The EC was also active in negotiating FTAs during this time period. UNITED NATIONS CONFERENCE ON TRADE AND DEVELOPMENT, TRADE AND DEVELOPMENT REPORT 2007, at 56 (2007), available at http://www.unctad.org/ en/docs/tdr2007_en.pdf [hereinafter TRADE AND DEVELOPMENT REPORT 2007].

27. Esserman, supra note 23, at 14.

28. Agreement Between the United States of America and the Hashemite Kingdom of Jordan on the Establishment of a Free Trade Area, U.S.-Jordan, Oct. 24, 2000, 41 I.L.M. 63, available at http://www.ustr.gov/assets/Trade_Agreements/Bilateral/Jordan/asset_upload file250_5112.pdf [hereinafter U.S.-Jordan FTA]. 
first term in 2002, he was able to obtain trade negotiating authority. ${ }^{29}$ This led the Bush Administration to further develop the components of the U.S. system for regionalism begun earlier - Trade and Investment Framework Agreements (TIFAs) ${ }^{30}$ Bilateral Investment Treaties (BITs) ${ }^{31}$ regional free trade initiatives, and bilateral FTAs. While some of these components for dealing with its goals on trade in terms of goods, services and investment had existed before, ${ }^{32}$ they then became part of a process for preparing a region or a country for a closer relationship with the United States. The focus of the system became pursuing trade agreements through regional initiatives and bilateral FTAs. The United States aimed its regional initiatives to cover every major continent or regionAsia, ${ }^{33}$ Africa, ${ }^{34}$ the Middle East, ${ }^{35}$ Latin America ${ }^{36}$ - other than Europe, its

29. Bipartisan Trade Promotion Authority Act of 2002, Pub. L. No. 107-210, 116 Stat. 993 , 19 U.S.C. $\$ \S 3804-3013$ (2002) [hereinafter TPA].

30. See USTR, Background on the Enterprise for ASEAN Initiative, http://www.ustr.gov/ Trade_Agreements/Regional/Enterprise_for_ASEAN_Initiative/Section_Index.html (last visited July 12,2008 ) [hereinafter EAI Background].

31. The United States has over 40 BITs in place. The United States uses a model BIT when it negotiates with partner countries. U.S. Bilateral Investment Treaty Program Fact Sheet, http://www.state.gov/e/eeb/rls/fs/2008/22422.htm (last visited Mar. 3, 2008).

32. The United States entered into its first BIT in 1980.

33. The EAI was launched in 2002 and produced the U.S.-Singapore Free Trade Agreement. United States-Singapore Free Trade Agreement, U.S.-Sing., May 6, 2003, 42 I.L.M. 1026, available at http://www.ustr.gov/Trade_Agreements/Bilateral/Singapore_FTA/ Final Texts/Section_Index.html [hereinafter U.S.-Singapore FTA]. The United States has also entered into negotiations with Malaysia and Thailand for bilateral FTAs. US/TPR, supra note 17 , at 114-115.

34. The regional initiative here was with the Southern African Customs Union (SACU). These FTA negotiations were launched in 2002, and the goal was to build on the success of the U.S. preference program for Africa, the African Growth and Opportunity Act (AGOA). USTR, BACKGROUND INFORMATION ON THE U.S.-SACU FTA, June 2, 2003, available at http://www.ustr.gov/Trade_Agreements/Bilateral/Southern_Africa_FTA/Background

Information_on_the_US-SACU_FTA.html. Active negotiations were suspended in 2006 but remain a "long term objective" according to the U.S. US/TPR, supra note 17, at 15.

35. The Middle East Free Trade Area Initiative (MEFTAI) launched in 2003 has produced three FTAs with Morocco, Bahrain and Oman. The U.S.-Morocco FTA was enacted in the U.S. in 2004. U.S.-Morocco Free Trade Agreement, U.S.-Morocco, June 15, 2004, 44 I.L.M. 544, available at http://www.ustr.gov/Trade_Agreements/Bilateral/Morocco_FTA/Fnal_Text Section_Index.html [hereinafter U.S.-Morocco FTA], The U.S.-Bahrain FTA was enacted in the U.S. in 2006. Agreement between the Government of the United States and the Government of the Kingdom of Bahrain on the Establishment of a Free Trade Agreement, U.S.-Bahr., 44 I.L.M 544, Sept. 14, 2004, available at http:///www.ustr.gov/Trade_Agreements/Bilateral/ Bahrain_FTA/Final_Text/Section_Index.html [hereinafter U.S.-Bahrain FTA]. The U.S. Oman FTA was also enacted in the U.S. in 2006. U.S.-Oman Free Trade Agreement, U.S.-Oman, Jan. 18, 2006, available at http://ustr.gov/Trade_Agreements/Bilateral/Oman_FTA/Final_Text/ Section_Index.html [hereinafter U.S.-Oman FTA]. The goal is to create a Middle East Free Trade Area.

36. The CAFTA initiative lead to Central American-Dominican Republic-United States Free Trade Agreement, 43 I. L.M. 514, Aug. 5, 2004, available at http://www.ustr.gov/ Trade_Agreements/Regional/CAFTA/CAFTA-DR_Final_Texts/Section_Index.html [hereinafter CAFTA-DR]. The agreement has entered into force for the United States, Guatemala, El Salvador, Honduras, Nicaragua and the Dominican Republic. Costa Rica could not enact 
main competitor in regionalism. The history of the regional initiatives to date has been mixed. Some initiatives, the FTAA and the South African Customs Union Initiative (SACU), have failed or been suspended. ${ }^{37}$ Other regional initiatives have produced or consolidated FTAs (CAFTA and the Enterprise for ASEAN Initiative (EAI)), while another one provides a framework for a series of bilateral FTAs (Middle East Free Trade Initiative (MEFTAI)).

In addition to introducing these initiatives, the Bush Administration accelerated both the pace of bilateral FTA negotiations and the process for their implementation. Every year from 2003 to 2007, the Office of the United States Trade Representative (USTR) completed and Congress approved at least one FTA $^{38}$ All of those agreements, with the exception of CAFTA-DR, have been bilateral agreements. Only one of those bilateral FTAs was formed with a developed country. ${ }^{39}$ By the time trade-negotiating authority expired in 2007, the Bush Administration had completed and signed FTAs with three other developing countries - Colombia, Panama, and South Korea - which it promised to pursue before Congress. ${ }^{40}$

CAFTA-DR without a public referendum, which was held on October 7, 2007. The FTA was approved by the slimmest of margins ( $51.48 \%$ in favor to $48.42 \%$ against). ICT Chamber Outlines Benefits of FTA for IT Industry, BUSINESS NEw AMERICAS, Oct. 17, 2007. Costa Rica had to request an extension of its March 2008 deadline in order to pass all of the implementing legislation needed to enact its free trade agreement obligations. Costa Rica To Request Extension for Deadline To Enter CAFTA, INSIDE U.S. TRADE, Vol. 26, No. 5, Feb. 1, 2008.

37. The FTAA process failed some of the negotiating countries, notably Brazil and Mexico, which resisted the comprehensive WTO-plus agreement being pushed by the United States. See Frederick M. Abbott, A New Dominant Trade Species: Is Bilateralism a Threat?, 10 I.E. L. J. 571,578 (2007) (Abbot notes that the U.S. offers a template of the areas it wishes to cover, and that developing FTA partners do not have many possibilities for amending it. Additionally, those countries which resisted the template, Brazil and Argentina in the FTAA negotiations, were left out and isolated when the U.S. began negotiations with other more willing partners in Latin America.).

38. The pattern is as follows: U.S.-Singapore (2003); U.S.-Chile (2003); U.S.-Australia (2004); U.S.-Morocco (2004); U.S.-CAFTA-DR (2004); U.S.-Bahrain (2006); U.S.-Oman (2006); and U.S.-Peru (2007). U.S.-Singapore FTA, supra note 33; U.S.-Chile Free Trade Agreement, U.S.-Chile, June 6, 2003, 42 I.L.M. 1026, available at http://ustr.gov/ Trade_Agreements/Bilateral/Chile_FTA/Final_Texts/Section_Index.html [hereinafter U.S.Chile FTA]; U.S.-Australia Free Trade Agreement, U.S.-Austl., May 18, 2004, 43 I.L.M. 1248, available at $\mathrm{http}: / /$ ustr.gov/Trade_Agreements/Bilateral/Australia_FTA/Final_Text/Section Index.html [hereinafter U.S.-Australia FTA]; U.S.-Morocco FTA, supra note 35; CAFTA-DR, supra note 36; U.S.-Bahrain FTA, supra note 35; U.S.-Oman FTA supra note 35; U.S.-Peru Trade Promotion Agreement, U.S.-Peru, April 12, 2006, available at http://www.ustr.gov/ Trade_Agreements/Bilateral/Peru_TPA/Final_Texts/Section_Index.html [hereinafter U.S.-Peru FTA].

39. Apart from Canada, the United States has only entered into one other FTA with a developed country, Australia.

40. Trade Promotion Authority expired in July 2007. Despite this, the Bush Administration has made approval of the pending FTAs with Colombia, Panama, and South Korea its top priority. The President's 2008 TRADE POLICY AGENDA, supra note 19, at 2; see also Statement of the U.S. Trade Representative Susan C. Schwab, Senate Fin. Comm. 1 (March 6, 2008), http://finance.senate.gov/hearings/testimony/2008test/030608sstest.pdf (setting out the goal of passing the pending FTAs before reaching a conclusion in the Doha Round of the WTO). 
Regional and bilateral FTAs became the "vehicle of choice" ${ }^{\text {41 }}$ for promoting trade liberalization during the Bush Administration. The primary reasons for this refocus on regionalism were two-fold. First, the United States again found that it could not achieve multilateral liberalization that satisfied all of its goals. The Doha Round at the WTO struggled and was eventually suspended over another impasse involving agricultural trade. ${ }^{42}$ Additionally, the United States proved unable to gain its preferred result of a comprehensive agreement that went beyond WTO standards with the developing countries in the Western Hemisphere. ${ }^{43}$ In response, the United States developed the theory and approach of "competitive liberalization"4 - moving forward towards liberalization on the multilateral, regional, and bilateral levels simultaneously. The theory was that regional and bilateral efforts would reenergize and focus WTO negotiations. The approach was to pursue like-minded FTA partners ${ }^{45}$ or those countries that satisfied another major U.S. goal in security and/or foreign policy. ${ }^{46}$ Second, the United States developed a model FTA that it wanted to

41. Esserman, supra note 23, at 14.

42. Sungjoon Cho, Doha's Development, 25 BERKELEY J. INT'L L. 165, 170 (2007) (reviewing the history of the Doha Round Suspension and prospects for its renewal); see also Press Release, WTO, Lamy Says New Negotiating Texts Set Stage for Crucial July Talks (July 10, 2008), http://www.wto.org/english/news_e/pres08_e/pr536_e.htm. Director-General Lamy argues that the trouble with Doha Round is about more than just these impasses. Id.

43. This happened with the failure of the FTAA negotiations.

44. "Competitive liberalization" is the terminology adopted by former U.S. Trade Representative Zoellick to describe the U.S. strategy: "By pursuing multiple free trade initiatives, the United States has created a 'competition for liberalization,' launching new global trade negotiations." POL. \& SOC'Y 1, 3-4,8 (2005) (noting that the United States pursues FTAs with countries willing to undertake economic reforms with regard to domestic regulatory practices).

45. Chile and the CAFTA countries, for example, were chosen as FTA partners because of their support for the U.S. positions in the FTAA negotiations. GOVERNMENT ACCOUNTABILITY Office (GAO), Intensifying Free Trade Negotiating Agenda Calls For Better ALLOCATION OF STAFF AND RESOURCES, GAO-04-233, at 42-43, 52 (2004), available at http://www.gao.gov/new.items/d04233.pdf [hereinafter GAO 2004 REPORT]; see also Nicola Phillips, US Power and the Politics of Economic Governance in the Americas, 47 LATIN AM. POL. \& SOC'Y 1, 3-4,8 (2005) (noting that the United States pursues FTAs with countries willing to undertake economic reforms with regard to domestic regulatory practices).

46. There is a direct link between being considered for a FTA and a country's support for U.S. security and foreign policy goals. USTR noted that the countries selected for bilaterals under MEFTAI were supporters of the U.S. objectives in the Middle East, and that the "CAFTA nations supported U.S. objectives in Iraq." GAO 2004 REPORT, supra note 46, at 8; see also Craig Van Grasstek, U.S. Trade Policy and Developing Countries: Free Trade agreements, Trade Preferences, and the DoHa Round, INT'l Centre for SustanNable TRADE AND DEVELOPMENT, INFORMATION NOTE 4, at 7 (2008), available at http://www.ictsd.org/pubs/US_Trade_Policy_and_Developing_Countries.pdf. Van Grasstek points out that the Bush Administration has a narrow set of foreign policy goals-largely, supporting the U.S. policy in the Middle East, cooperating in anti-narcotic activity and agreeing to leave the developing country coalition at the WTO (the Group of 21). He also notes that FTAs were entered into with moderate Middle East States and that, of the recent FTAs (including those not yet enacted), every partner country (S. Korea, Colombia, Panama and CAFTA States) was a member of the "coalition of the willing," except for Guatemala. Id. 
keep pushing. ${ }^{47}$ Getting partners to agree to the model FTA was paramount because the model covered all U.S. interests and stood as an illustration of and best hope for pushing U.S. preferences of worldwide trade discipline. What the United States wanted to offer was a true model-an example for imitation or emulation-for the WTO. Should the United States prove unable to move the WTO completely towards its agenda, the FTAs would guarantee achievement on a regional level and, if successful, provide additional credibility for the U.S. positions they embody. ${ }^{48}$

The use of a model approach was even extended to how the United States chose its FTA partners. In its recent FTAs-those negotiated after 2002 under the TPA-USTR developed a list of factors for determining which countries should be U.S. FTA partners. The thirteen-factor list of $2002^{49}$ was reduced in recent years to six. ${ }^{50} \mathrm{~A}$ review of both sets of factors reveals what motivated the United States to enter into model FTAs. The factors center upon issues that always resonate in U.S. trade policy-the level of domestic support for an FTA, ${ }^{51}$ the level of commitment by target countries to trade liberalization and

47. In its review of how the Bush Administration has consulted over FTAs entered into under Trade Promotion Authority, the GAO interviewed the officials responsible for trade policy and negotiations at USTR and the Departments of Agriculture, Commerce, Labor, State and Treasury, the agencies which, along with USTR, form an interagency group to propose potential FTA partners to the President. GAO, AN ANALYSIS OF FREE TRADE AGREEMENTS AND CONGressional and Private Sector Consultation under Trade Promotion Authority, GAO-08-59, at 1-2 (2007), available at http://www.gao.gov/new.items/d0859.pdf [hereinafter GAO 2007 REPORT]. As part of its analysis of the U.S. FTAs, the GAO examined the U.S. strategy for pursuing FTAs and found it had two major elements-using the theory of competitive liberalization and seeking comprehensive or "gold standard" bilateral and regional FTAs. Id. at 17-18. According to the GAO, the recent U.S. FTAs "have a number of absolute requirements, based on the model USTR seeks to use." Id. at 18. In its Trade Policy Review Report to the WTO, the United States also noted that its regional trade agreements could "become models for future multilateral liberalization in new areas such as agriculture, services, investment and environmental and labor standards." US/TPR, supra note 17, at 14.

48. USTR, The President's 2003 TRADE Policy AGENDA 10 (2003) available at http://www.ustr.gov/assets/Document_Library/Reports_Publications/2003/2003_Trade_Policy_ Agenda/asset_upload_file666_6142.pdf (stating that the regional and bilateral FTAs promote the broader trade agenda by "serving as models, breaking new negotiating ground, and setting high standards."); see also GAO 2004 REPORT, supra note 46, at 17.

49. GAO 2004 REPORT, supra note 46 , at 7-10. The thirteen factors were: Congressional guidance; (2) business and agricultural interest; (3) special product sensitivities; (4) serious political will of the prospective partner to undertake needed trade reforms; (5) willingness to implement other reforms; (6) commitment to WTO and other trade agreements; (7) contribution to regional integration; (8) support of civil society groups; (9) cooperation in security and foreign policy; (10) need to counter FTAs that place U.S. commercial interests at a disadvantage; (11) need to do FTAs in each of the world's major regions; (12) need to ensure a mix of developed and developing countries; and (13) demand on USTR resources. According to USTR, these factors did not have relative weights. Id. at 7 .

50. The six factors were: (1) country readiness; (2) economic/commercial benefit; (3) benefits to the broader trade liberalization strategy; (4) compatibility with U.S. interests; (5) Congressional/Private-sector support; and (6) U.S. government resource constraints. $I d$. at 9-10.

51. Factors 1-3 of the earlier list are on Congressional guidance, business and agricultural 
reform, ${ }^{52}$ the cooperation of target countries in security and foreign policy matters, and strategic plans to counter other trading nations. ${ }^{53}$

\section{ELEMENTS OF THE U.S. MODEL FTA}

The United States only enters into FTAs and each one must satisfy its model. The FTA is the chosen form of regionalism because it is subject to only limited multilateral discipline - under GATT Article XXIV and the General Agreement on Trade in Services (GATS) Article V-and limited WTO oversight. $^{54}$ In order to satisfy GATT Article XXIV, the parties to an FTA must agree: (1) to eliminate duties and other restrictive regulations on

interest and special product sensitivities. Id. at 7. According to the GAO's interviews with USTR, it consults with Congress before and after FTA partner selection "to ensure support and eventual congressional approval." Id. at 7. Additionally, USTR officials also examine public support, particularly from business and agricultural interests, and assess how the FTA will affect certain sectors that have always been of interest, textiles and sugar. Id.at 7.

The Executive Branch rarely moves forward if there is political opposition. See Gantz, supra note 17 , at 187 ("Even the most free trade oriented administrations . . . are not likely to brave domestic political opposition unless there is enormous pressure from the business community to move forward and some semblance of bipartisan support in Congress."):

52. Factors 4 through 6 of the earlier list-the political will of potential FTA partners to implement trade reform and other reforms-deal with whether the FTA partner is willing to undertake obligations inherent in a U.S.-led FTA. In judging these factors, USTR examines the target country's "trade capabilities" and its "track record in meeting current trade obligations." GAO 2004 REPORT, supra note 46, at 7. Since USTR regards FTAs as a "development tool," it is crucial that the FTA partner be willing to put in place other economic reforms. In choosing an FTA partner, USTR tries to make sure that the country understands "1) how important it is to make this commitment to reform and 2) the extent of the obligations that a comprehensive FTA with the U.S. involves." Id. at 7-8.

An example of the type of other reforms undertaken by FTA partners were those taken by Chile to eliminate price controls and privatize state-owned enterprises. Id. at 42.

According to USTR, the first factor of the new six factor list, country readiness, involves a "country's political will, trade capabilities, and rule of law systems." Id. at 9 . The interagency review done to review FTA partners means that different U.S. agencies examine different issues when evaluating a partner under this factor. USTR examines trade policy issues while the Treasury Department looks at a potential FTA partner's "overall macroeconomic stability and the strength of its financial or banking systems." Id. at 9.

53. Factor 10 of the earlier list-countering FTAs that place the U.S. commercial interests at a disadvantage-deals with one of the realities of the proliferation of regional agreements. Once competing trading nations begin to enter their own FTAs with a potential partner, the United States would be at a disadvantage. This was the primary reason the United States entered into the U.S.-Chile FTA. USTR noted that given Chile's other FTAs (with Canada, Mexico and the EC), Chile had reduced its purchases of U.S. exports by almost one-third. Id. at 8,42 (noting that the United States lost export market share in Chile due to its other FTAs).

54. GATT, supra note 2, at art. XXIV.; GATS, supra note 16, at art. V. The WTO requires Member States which enter regional trade agreements to notify these to the organization. The Committee on Regional Trade Agreements (CRTA) has jurisdiction over these agreements. The WTO agreed in 2006 to establish a review process for these agreements that would include a factual report about the operation of each regional trade agreement. To date, the CRTA has made only limited progress on finalizing its reports. WTO, WORLD TRADE REPORT 2007, at 306 (2007), available at http://www.wto.org/english/res_e/booksp_e/anrep_e/ world_trade_report07_e.pdf [hereinafter WORLD TRADE REPORT 2007]. 
substantially all trade between constituent territories originating in those territories; (2) to not raise duties or other restrictive regulations against nonmembers upon formation of the free trade area; and (3) to achieve these objectives within a reasonable time. ${ }^{55}$ There are similar requirements under GATS Article V. ${ }^{56}$

As long as the United States and its partners aim for eliminating duties and other restrictions on almost all trade, avoid accompanying this liberalization with a raising of barriers to non-members, and do so within a relatively short

55. GATT, supra note 2 , at art. $\operatorname{XXIV(5)(b),~8(b).~}$

5 (b) With respect to a free-trade area . . . the duties and other regulations of commerce maintained in each [o]f the constituent territories and applicable at the formation of such free-trade area ... shall not be higher or more restrictive than the corresponding duties and other regulations of commerce existing in the same constituent territories prior to the formation of the free-trade area.

(8) For purposes of this Agreement:

(b) A free-trade area shall be understood to mean a group of two or more customs territories in which the duties and other restrictive regulations of commerce ... . are eliminated on substantially all the trade between the constituent territories in products originating in such territories.

Id. at art. XXIV(5)(b), 8(b).

Thus, Article XXIV, intended to allow regional arrangements "as long as they satisfied three requirements: transparency, commitment to deep-intraregional liberalization, and neutrality vis-à-vis third parties." WORLD TRADE REPORT 2007, supra note 55, at 305.

56. GATS, supra note 16 , at art. V.

This Agreement shall not prevent any of its Members from being a party to or entering into an agreement liberalizing trade in services between or among the parties to such an agreement, provided that such an agreement: has substantial sectoral coverage, and provides for the absence or elimination of substantially all discrimination, in the sense of Article XVII, between or among the parties, in the sectors covered under subparagraph (a), through: elimination of existing discriminatory measures, and/or prohibition of new or more discriminatory measures, either at the entry into force of that agreement or on the basis of a reasonable time-frame, except for measures permitted under Articles XI, XII, XIV and XIV bis.

In evaluating whether the conditions under paragraph 1(b) are met, consideration may be given to the relationship of the agreement to a wider process of economic integration or trade liberalization among the countries concerned.

Where developing countries are parties to an agreement of the type referred to in paragraph 1 , flexibility shall be provided for regarding the conditions set out in paragraph 1, particularly with reference to subparagraph (b) thereof, in accordance with the level of development of the countries concerned, both overall and in individual sectors and subsectors.

Id. at Art. V(1), (2) (footnote omitted).

The major elements of GATS art. V are: 1) "substantial sectoral coverage" of the trade services among the parties; 2) that "substantially all discrimination" has to be eliminated either at entry into force or on a "reasonable time-frame"; and 3) that the agreement area not raise the overall level of barriers compared to before the formation of the economic integration area. WORLD TRADE REPORT 2007, supra note 55, at 307. 
time period, they have met the requirements of GATT Article XXIV. ${ }^{57}$ All U.S. FTAs have aimed for eliminating most, if not all, duties and restrictions on all trade (as opposed to "substantially all"). ${ }^{58}$ In addition, although U.S. FTAs do result in trade diversion, whereby non-members lose out on market access to FTA parties, ${ }^{59}$ the United States has never and would not negotiate any formal restrictions against other trading nations as part of entering into an FTA. With regard to the time it takes to complete the liberalization, U.S. FTAs aim to eliminate most duties and restrictions within ten years of enactment of the agreement. $^{60}$ Similarly, once GATS art. V went into effect, all U.S. FTAs were focused on eliminating existing discriminatory measures (and prohibiting new or more discriminatory measures) on trade in services covering almost all service sectors within a similar time frame. Given the GATT/WTO history of not disapproving of regional arrangements, ${ }^{61}$ it has been easy for the United States to align its regionalism goals with its multilateral obligations.

Other reasons why the FTA has been the favored form are the flexibility it allows and the limited integration it demands. There are no requirements under the GATT/WTO as to either the subject areas or the respective depth of those areas that can be embraced by an FTA. Consequently, the United States has used this freedom to include a significant number of issues-those covering

57. The requirements under GATT Article XXIV and GATS Article V have proven easy to satisfy in part because of the WTO failure to reach consensus on the interpretation of such crucial aspects of the definitions as duties and "other restrictive regulations" and "substantially all trade" in Article XXIV and "substantially all discrimination" in GATS Article V. See WORLD TRADE REPORT 2007, supra note 55, at 308-312 for a discussion of the GATT art. XXIV and GATS art. V elements, which have not been fully defined, and how they might be interpreted.

58. For illustrations, see CAFTA-DR, supra note 36, at Ch. 3, Annex 3.3; see also Summary of the U.S.-Peru FTA, available at http://www.ustr.gov/assets/Document_Library/ Fact_Sheets/2007/asset_upload_file585_13067.pdf; U.S.-Peru FTA, supra note 38, at Ch. 2, Annex 2, available at http://www.ustr.gov/Trade_Agreements/Bilateral/Peru_TPA/ Final_Texts/Section_Index.html; Short Summary of the CAFTA-DR, available at $\mathrm{http}: / /$ www.ustr.gov/assets/Trade_Agreements/Bilateral/CAFTA/Briefing_Book/asset_ upload_file834_7179.pdf.

59. After NAFTA, trade increased between the three parties, some of it at the expense of non-members. GARY CLYDE HUfBAUER \& JeFFREY J. SCHOTT, NAFTA REVISITED: ACHIEVEMENTS AND CHALLENGES, RECOMMENDATIONS FOR NORTH AMERICAN INTEGRATION 1819 (Inst. Int'l Economics 2005).

60. The GATT art. XXIV requirement that an FTA must be completed within a "reasonable period of time" has been interpreted by the WTO to mean that an FTA should be implemented in no more than ten years except for "exceptional cases." WORLD TRADE REPORT 2007, supra note 55 , at 310 .

61. Historically, the GATT/WTO have never disapproved of a regional agreement. According to the Sutherland Report on the future of the WTO: "In practice there are now just too many WTO Members with interests in their own regional or bilateral arrangements for a critical review of PTA terms to take place and for consensus on their conformity to be found." Peter Sutherland et al., The Future of the WTO: Addressing Institutional Challenges in the New Millenium, 22, 77 (2004), available at http://www.wto.org/english/thewto_e/10anniv_el future_wto_e.pdf. For a discussion of the rules regarding regionalism see WORLD TRADE REPORT 2007, supra, notes 55-58. 
trade in services and trade-linked issues - into its FTAs. Moreover, since the creation of an FTA consists largely of eliminating barriers, rather than crafting common legislation (as required by the customs union, the other form of regionalism under the $\mathrm{GATT}^{62}$ ), the FTA parties do not have to create a supranational institution to achieve their goals. ${ }^{63}$

The limited multilateral discipline and the resulting flexibility combined to allow the United States to develop a model FTA. There is widespread agreement by the U.S. government itself ${ }^{64}$ and observers that the United States has been developing a model for FTAs. ${ }^{65}$ What it has pursued over the last fifteen years has been FTAs based on two models: the NAFTA model and an adaptation of it, the WTO-plus model. As would be expected, the major aspects of the NAFTA model have remained the same in the later model.

Consequently, this analysis will begin with the common aspects of the models - aspects of the model which have been retained. One obvious feature of the NAFTA model is its design which consists of sixteen subject matter areas, ${ }^{66}$ with five other chapters devoted to institutional arrangements and dispute settlements. The treaty text itself, not including the lengthy tariff schedules, is heavily drafted and runs more than three hundred pages. Each chapter is structured the same way-with general definitions appearing at the beginning or end, followed by a section on general obligations and ending with detailed annexes that contain either exceptions and reservations to or special implementation aspects of the general obligations. ${ }^{67}$ NAFTA ended up with

62. Under the terms of GATT art. XXIV, countries forming a customs union must adopt a common external tariff. In effect, this means that the countries must adopt a common trade policy towards non-members. GATT, supra note 2, at art. XXIV(8)(a).

63. A distinction has been suggested for different types of integration efforts. Negative integration by countries involves the removal of discrimination in national economic rules and policies under joint and authoritative surveillance. This would be a free trade area. By contrast, positive integration involves the transfer "of public-market-rule-making and policy making powers from the participating politics to the union level." This would be a customs union. Jacques Pelkmans, The Institutional Economics of European Integration, in INTEGRATION THROUGH LAw: EUROPE AND THE AMERICAN FEDERAL EXPERIENCE 318, 321, 340-41 (Mauro Capelliti, Monica Seccombe \& Joseph Weiller eds., Walter de Gruyter \& Co., 1986).

64. See GAO 2007 REPORT, supra note 48, at 9 (based on data from 2005/2006); THE PRESIDENT's 2003 TRADE POLICY AGENDA, supra note 49, at 2; US/TPR, supra note 17, at 1625.

65. See Abbott, supra note 37, at 578; see Hufbauer \& Schott, supra note 59, at 56-57.

66. The International Trade Commission (ITC) reviewed the first comprehensive FTAs based on the NAFTA model in a report in 2005. According to its analysis, the model FTA consists of twenty to twenty-five chapters, all organized in the same order in all of the agreements, with annexes (to address non-conforming measures with regard to services), sometimes containing separate chapters on specific industry sectors or regulatory issues. U.S. INT"L TRADE COMMISSION (ITC), THE IMPACT OF TRADE AGREEMENTS IMPLEMENTED UNDER Trade Promotion Authority, INV. No. TA-2103-1, USITC Pub. 3780, at 2-2, Table 2.1 (2005), available at http:/hotdocs.usitc.gov/docs/pubs/332/pub3780.pdf [hereinafter ITC IMPACT REPORT] (comparing the structure/contents Singapore, Chile and Morocco agreements on a grid).

67. In order to understand which general obligations a party has undertaken in any 
two side agreements (on labor rights and environment cooperation) that were added to the legal obligations of the parties. All of the later FTAs follow the same design, even the same basic ordering of subject matter chapters. ${ }^{68}$ Instead of side agreements, however, the later FTAs have side letters that are considered to be part of the text. ${ }^{69}$

The major elements of the NAFTA model are its focus on the GATT, its scope and coverage, its limited institutionalism, and its diffuse dispute settlement system. Each of these elements satisfies deeply-held multilateral and domestic trade policy preferences. These can best be illustrated by examining each major element of the NAFTA model.

The NAFTA model embraces the GATT in several ways-through GATT compliance, GATT modeling and GATT adoption. The GATT compliance can be seen in the first Article of the agreement. According to Article 101, NAFTA parties "consistent with Article XXIV of the General Agreement on Tariffs and Trade, hereby establish a free trade area." ${ }^{170}$ All U.S. FTAs begin the same way. ${ }^{71}$ The only alteration has been to add compliance with GATS Article V to this commitment. ${ }^{72}$ Not only do the Parties announce GATT compliance as the goal under the NAFTA model, but they also commit themselves to respecting their respective rights and obligations under the GATT ${ }^{73}$ This announcement of the FTA's compliance with the GATT and the parties' adherence to the multilateral rules signals the desire of the United States (and its partners) to keep regionalism in its place. ${ }^{74}$ An FTA may compromise non-discrimination but only within the parameters established by the multilateral system.

The NAFTA model reinforces this GATT commitment by modeling the language of core obligations regarding trade in goods after GATT provisions. This is done in two ways: either the NAFTA provision adopts the GATT obligation as the standard for the FTA, or it models the language of the

substantive area, for example, trade in goods or trade in services, you have to examine the reservations it has taken. The annexes, therefore, are where the deals are struck.

68. Compare the design of the U.S.-Chile FTA, supra note 38, with the design of the U.S.Peru FTA, supra note, 38.

69. Recent U.S. FTAs have large numbers of side letters. These are negotiated and drafted in response to the Congressional/Executive Branch cooperation over implementing legislation for FTAs. See J.F. HORNBECK AND William H. COOPER, CONG. RESEARCh SERVICE, Trade Promotion Authority (TPA): IsSUES, OPTIONS, AND PROSPECTS FOR RENEWAL, CRS - 13 (2007), available at http://fpc.state.gov/documents/organization/78415.pdf (noting that Congress insists on additions or clarifications to trade agreements by this process).

All U.S. FTAs have side letters, but not all side letters are the same. Some are "records of understanding while others can amount to agreed upon interpretations that can add to or make effective changes." ITC IMPACT REPORT, supra note 67, at 2-6.

70. NAFTA, supra note 7, at art. 101.

71. The provision stating that the intent of the parties to establish a GATT-compliant FTA is always the first provision in a U.S. FTA.

72. Compare NAFTA, supra note 7, at art. 101, with U.S.-Peru FTA, supra note 38, at art. 101.

73. NAFTA, supra note 7, at art. 103.

74. See US/TPR, supra note 17 , at $\mathrm{X}$. 
NAFTA rule on the corresponding GATT rule. For example, the core obligation in NAFTA is to apply national treatment to the goods of another party. In Article 301, the provision does not repeat the GATT language on the concept ${ }^{75}$ but instead states that the parties "shall accord national treatment to the goods of another Party in accordance with Article III of the General Agreement on Tariffs and Trade (GATT), including its interpretive notes." 76 Article 301 concludes by incorporating Article III of GATT, its interpretive notes and any equivalent provision of a successor agreement into NAFTA. ${ }^{77}$ By contrast, Article 309 on Import and Export Restrictions adopts its general obligations using most of the same language of the corresponding GATT provision in Article $\mathrm{XI}^{78}$ and it also incorporates the GATT provision.

\section{GATT, supra note 2, art. III(4) provides:}

The products of the territory of any contracting party imported into the territory of any other contracting party shall be accorded treatment no less favourable than that accorded to like products of national origin in respect of all laws, regulations and requirements affecting their internal sale, offering for sale, purchase, transportation, distribution or use. The provisions of this paragraph shall not prevent the application of differential internal transportation charges which are based exclusively on the economic operation of the means of transport and not on the nationality of the product.

Id. at art. III(4).

76. NAFTA, supra note 7, at art. 301(1).

77. Article 301 of NAFTA on National Treatment provides:

Each party shall accord national treatment to goods of another Party in accordance with Article III of the General Agreement on Tariffs and Trade (GATT), including its interpretive notes, and to this end Article III of the GATT and its interpretive notes, or any equivalent provision of a successor agreement to which all Parties are party, are incorporated into and made part of this Agreement.

Id. at art. 301 .

After the completion of the Uruguay Round, which adopted GATT in 1994, the language was changed for all later FTAs. Compare NAFTA, supra note 7, at art. 301, with CAFTA-DR, supra note 36 , at art. 3.2 :

Each party shall accord national treatment to the goods of another Party in accordance with Art. III of the GATT 1994, including its interpretive notes, and to this end Article III of GATT 1994 and its interpretive notes are incorporated into and made part of this Agreement, mutatis mutandis.

CAFTA-DR, supra note 36, at art. 3.2.

78. NAFTA Article 309(1) provides:

Except as otherwise provided in this Agreement, no Party may adopt or maintain any prohibition or restriction on the importation of any good of another Party or on the exportation or sale for export of any good destined for the territory of another Party, except in accordance with Article XI of the GATT, including its interpretative notes, and to this end Article XI of the GATT and its interpretative notes, and to this end Article XI of the GATT and its interpretative notes, or any equivalent provision of a successor agreement to which all Parties are party, are incorporated into and made a part of this Agreement.

Id. at art. 309(1). Compare NAFTA, supra note 7, at art. 309(1), with GATT, supra note 2, at art. XI, which provides:

No prohibitions or restrictions other than duties, taxes or other charges, whether made effective through quotas, import or export licenses or other measures, shall 
NAFTA displays the same technique of GATT modeling with regard to trade in services. In this instance, however, the language of NAFTA Article $1202^{79}$ on National Treatment mirrors the language of what became GATS Article II. ${ }^{80}$ The United States and its partners borrowed the language from the draft of the GATS text that was under consideration during the Uruguay Round negotiations. At the time NAFTA was being completed it was clear that the regional FTA would extend trade discipline to trade in services. By contrast, it was not yet clear that the GATT would complete the Uruguay Round and adopt GATS. Subsequent U.S. FTAs simply follow the NAFTA model on this. ${ }^{81}$ This same practice is extended even to the General Exceptions allowed under the FTA. Rather than negotiate freely over what should constitute an excuse for violations of core obligations (such as national treatment and the prohibition on quantitative restrictions), NAFTA adopts ${ }^{82}$ the limited exceptions allowed

be instituted or maintained by any contracting party on the importation of any product of the territory of any other contracting party or on the exportation or sale for export of any product destined for the territory of any other contracting party.

GATT, supra note 2, at art. XI(1).

79. NAFTA art. 1203 provides that "[e]ach Party shall accord to service providers of another Party treatment no less favorable than it accords, in like circumstances, to service providers of any other Party or of a non-Party." NAFTA, supra note 7, at art. 1203.

80. GATS art. II provides that "[w]ith respect to any measure covered by this Agreement, each Member shall accord immediately and unconditionally to services and service suppliers of any other Member treatment no less favorable than that it accords to like services and service suppliers of any other country." GATS, supra note 16, at art. II(1).

The NAFTA parties also adopted the same language as GATS on National Treatment. Compare NAFTA, supra note 7, at art. 1202, with GATS, supra note 16, at art. XVII(2). The GATS language, in turn, was patterned after the GATT language on MFN and National Treatment.

81. See U.S.-Chile FTA, supra note 38, at art. 11.2. The only difference in the language from NAFTA is that it uses the words "service suppliers" instead of "service providers." The provision also has an interpretive note which states that "[t]he Parties understand that "service suppliers' has the same meaning as 'services and service suppliers' in Article II:1 of GATS." Id. at art.11.3 n.3.

82. GATT, supra note 2 , at art. XX.

Subject to the requirement that such measures are not applied in a manner which would constitute a means of arbitrary or unjustifiable discrimination between countries where the same conditions prevail, or a disguised restriction on international trade, nothing in this Agreement shall be construed to prevent the adoption or enforcement by any contracting party of measures:

necessary to protect public morals; necessary to protect human, animal or plant life or health; (c) relating to the importations or exportations of gold or silver; (d) necessary to secure compliance with laws or regulations which are not inconsistent with the provisions of this Agreement, including those relating to customs enforcement, the enforcement of monopolies operated under paragraph 4 of Article II and Article XVII, the protection of patents, trade marks and copyrights, and the prevention of deceptive practices; relating to the products of prison labour; imposed for the protection of national treasures of artistic, historic or archaeological value; relating to the conservation of exhaustible natural resources if such measures are made effective in conjunction with restrictions on domestic production or consumption.... 


\section{under Article XX of the GATT. ${ }^{83}$}

Two consequences flow from this drafting decision. First, the NAFTA conceptions of national treatment and general exceptions will always be informed by the years of experience with the concepts at the multilateral level, including all later interpretations, thus ensuring legal coherence. Second, by adopting the GATT concepts, the drafters could offer the NAFTA parties a choice of forum option for the settlement disputes. With limited exceptions, if a NAFTA party encounters discrimination with regard to trade in goods, it can seek relief not just in the NAFTA dispute settlement system but also in the multilateral system. ${ }^{84}$ Article 2005 allows such a choice of forum, subject to limitations, on disputes regarding "any matter" arising under both NAFTA and the GATT, and "any agreement negotiated thereunder, or any successor agreement." 85

The NAFTA model established the scope and coverage of all later U.S. FTAs. The subject matter topics go beyond tariff and non-tariff barriers to trade in goods to cover other areas of interest to U.S. firms and traders-trade in services, investment, competition policy and intellectual property rights. The subjects covered in the first part are those related to Trade in Goods ${ }^{86}$ - General Obligations, ${ }^{87}$ Rules of Origin and special Rules of Origin, ${ }^{88}$ Customs

83. NAFTA, supra note 7, at art. 2101(1).

1. For purposes of:

Part Two (Trade in Goods), except to the extent that a provision of that Part applies to services or investment, and

Part Three (Technical Barriers to Trade), except to the extent that a provision of that Part applies to services, GATT Article XX and its interpretative notes, or any equivalent provision of a successor agreement to which all Parties are party, are incorporated into and made part of this Agreement.

The Parties understand that the measures referred to in GATT Article XX(b) include environmental measures necessary to protect human, animal or plant life or health, and that GATT Article $\mathrm{XX}(\mathrm{g})$ applies to measures relating to the conservation of living and non-living exhaustible natural resources.

Id. at art. 2101(1).

84. NAFTA does allow the complaining party the choice of forum. However, it gives any third party the right to force a dispute to NAFTA. NAFTA, supra note 7, at art. 2005(2). The NAFTA dispute settlement system is also designated as the forum if the respondent requests such an option in writing, in disputes involving Article 104 (Relation to Environmental and Conservation Agreements) and the standards measures in NAFTA (Sanitary and Phyto-sanitary standards and Technical Barriers to Trade). Id. at art. 2005(2-4), (6).

85. Id. at art. 2005(1). All U.S. FTAs have the same general choice of forum option. Compare NAFTA, supra note 7, at art. 2005, with CAFTA-DR, supra note 36, at art. 20.3.

86. In NAFTA, the part on trade in goods (Part II) always covers both Market Access and National Treatment. This is true for all later U.S. FTAs as well. Included in this part are also special provisions related to sensitive sectors of trade. See NAFTA, supra note 7, at ch. 2. In later agreements, there are often breakouts of some of these provisions for separate chapters. See U.S.-Peru FTA, supra note 38, at chs. 2,3.

87. The key general obligations are tariff elimination (art. 302) and national treatment (art. 301). NAFTA, supra note 7, at 301, 302.

88. The Rules of Origin chapters are key to the operation of any FTA. The rules define which goods "originate in" a Party and, therefore, qualify for duty-free treatment. Countries 
Procedures, ${ }^{89}$ Agriculture, ${ }^{90}$ Sanitary and Phyto-sanitary Standards and Technical Barriers to Trade ${ }^{91}$ and Safeguard rules. ${ }^{92}$ The Trade in Goods part of the NAFTA model is built around two main themes-flexibility and accommodation of special interests. That is achieved by several drafting techniques. First, the tariff elimination required to actually open up a market is phased-in for products and can run from the date of enactment to ten years or beyond. $^{93}$ This flexibility was built in to allow the FTA partners to negotiate for time - since all openings for sensitive products are back-loaded ${ }^{94}$ - to adjust for products that will not be competitive when the FTA goes into force. A similar product-based accommodation is provided for by the design of the rules of origin.

The NAFTA rules are widely regarded as generally restrictive (to limit the trade benefits of the agreement to parties) and highly variable across product categories. ${ }^{95}$ These features allow the FTA parties to shape specialized rules of origin that will protect certain sectors from competition.

A separate chapter exists to cover obligations by the Parties to liberalize

negotiating an FTA are concerned that, without a strict rule of origin, non-member countries will exploit the FTA party with the lowest external tariff as a point of entry into the free area (thereby creating trade deflection) in order to benefit from the duty-free system. See JOHN LAMBrinidis, The Structure, Function and Law of a Free Trade AREA: The European Free Trade Association 91-92 (Frederick A. Praeger, London Institute of World Affairs 1965).

Chapter Four of NAFTA contains the general rules of origin for the agreement. See NAFTA, supra note 7, at art. 401 (originating Goods). NAFTA, however, does have special rules of origin requiring a specified level of regional value for automobiles and another special rule for textiles.

89. NAFTA, supra note 7 , at ch. 5 .

90. Id. at ch. 7(A).

91. Id. at chs. 7(B) \& 9.

92. Id. at ch.8 (entitled Emergency Action).

93. Id. at Annex 302.2. NAFTA phased out tariff elimination gradually with some tariffs on some goods being dropped immediately while others were eliminated at five, ten, and fifteen year intervals.

94. By pushing out the time frame for eliminating tariffs on sensitive products, the parties to a FTA gain adjustment time.

The United States first encountered the issue of how to balance out obligations on tariff elimination - the single biggest factor towards opening up trade in goods-when it negotiated with Mexico during NAFTA. Mexico took great efforts to make the United States understand its status as a developing country and the adjustments it would have to make. HERMAN vON BerTRAB, Negotiating NAFTA: A MEXICAN ENvoY's ACCOUNT 46 (The Ctr. For Strategic and Int'l Studies 1997).

95. This product-specific aspect of the rules of origin is used to shield products and industries. See generally HUFBAUER \& SCHOTT, supra note 59, at 474-476 on how the NAFTA rules could be improved to avoid the protectionist aspects. In addition, restrictive and product specific rules are more difficult for traders to apply (and require extensive record-keeping) customs officials to enforce. This has been found by one study to offset the advantage of dutyfree status granted under NAFTA. Bolormea Tumanchandra, Oliver Cadot, Antoni Estevadeordal, Jaime deMelo, Akiko Suwa-Eisenman \& Jose Anson, Rules of Origin in NorthSouth Preferential Trading Arrangements with an application to NAFTA, 13 REV. INT'L ECON. 612-629 (2005). 
and open competition for Government Procurement. ${ }^{96}$ This chapter also contains tendering procedures that the parties are to follow in this area. ${ }^{97}$ By adding a chapter in this area, the United States was attempting to gain access to a relatively closed-off market for goods and services that was relatively undisciplined at the WTO. ${ }^{98}$

There are several chapters covering trade in services - Cross Border Trade in Services ${ }^{99}$ and specialized chapters on heavily regulated services, Telecommunications and Financial Services. ${ }^{100}$ In the chapter on trade in services, the NAFTA model seeks liberalization well beyond that which was ultimately obtained in GATS. ${ }^{101}$ The technique was to use the negative list approach for negotiating offers in this area. Unless a NAFTA party expressly reserved a services sector from liberalization, it was to be opened to the general obligations on non-discrimination and market access. ${ }^{102}$ The use of the negative list approach has three consequences - it forces greater liberalization, locks in prior liberalization, and guarantees that any new service will be automatically covered by the agreement. ${ }^{103}$ The chapter on investment included not only rights for investors but also neutral, binding investor/state arbitration to resolve disputes on these issues. ${ }^{104}$ The final substantive sections in the NAFTA model are on Competition policy, ${ }^{105}$ Temporary Entry for Business Persons ${ }^{106}$ and Intellectual Property. ${ }^{107}$ The Intellectual Property chapter covers

96. NAFTA, supra note 7 , at $\mathrm{ch}$. 10. The chapter is built around providing national treatment to NAFTA firms that want to bid for government procurements. Many governments limit access to this form of trade to national firms, so obtaining a market access commitment here was significant since "government spending on goods and services can amount to 10 percent of GDP or more." See TRADE AND DEVELOPMENT REPORT 2007, supra note 26, at 60. All U.S. FTAs cover government procurement. The FTAs on this topic open up more trade than similar commitments made under the WTO's Agreement on Government Procurement (AGP) since only the U.S. and Canada are members of the AGP whereas each developing country FTA partner must agree to a Government Procurement chapter.

97. NAFTA, supra note 7 , at ch. 10(B).

98. The Agreement on Government Procurement is a plurilateral agreement of the WTO. Agreement on Government Procurement, Apr. 15, 1994, 33 I.L.M. 1125-1226 (1994), at Annex 4(b). Member States can choose whether or not to accede to the agreement. As a result, it has a much smaller membership, with approximately 40 countries as opposed to the 150 Members of the WTO. Id.

99. NAFTA, supra note 7, at ch. 12.

100. Id. at chs. $13,14$.

101. GATS used the "positive list" approach to scheduling commitments on trade in services. This means a country must liberalize only in those areas and to the extent specified in the list. With regard to any service sector left off a GATS schedule, a WTO member retains complete control over market access and regulation. See TRADE AND DEVELOPMENT REPORT 2007 , supra note 26 , at 60 .

102. NAFTA, supra note 7 , at arts. 1202, 1203. The non-conforming measures or exceptions taken by each Party are attached as an Annex. Id. at Annex I.

103. ITC IMPACT REPORT, supra note 67, at 2-14.

104. The NAFTA Chapter 11 on investment covers investor rights and protections in Part A, and provides for binding investor/state arbitration in Part B. NAFTA, supra note 7, at ch. 11 .

105. Id. at ch. 15.

106. Id. at ch. 16 . 
not only IP rights but also enforcement obligations which must be undertaken by the parties to give them effect. In the NAFTA model, side agreements were added, in response to a new President and Congress, on the impacts of trade in the areas of labor rights and environmental cooperation. ${ }^{108}$ The labor and environmental agreements do not create substantive obligations in each area. Instead, in each, the parties are obligated to enforce its labor laws and its laws on environmental protection. ${ }^{109}$

The NAFTA model is notable for what it omits from the scope of substantive obligations. Labor mobility is limited solely to temporary entry. There are no rules on the content of the unfair trade statutes (anti-dumping and countervailing duty law). ${ }^{110}$ Agriculture, although covered, does not eliminate many of the practices (particularly production subsidies) ${ }^{111}$ that limit liberalization. None of these issues were considered possible from the U.S. perspective. None of the later U.S. FTAs have altered this assessment.

The final major element of the NAFTA model is its insistence on limited institutionalism and multiple dispute settlement systems. The two matters are connected. The United States was not interested in creating any supranational institution with legislation-creating or adjudicative authority with Canada and Mexico. Consequently, NAFTA established the most skeletal form of administration. ${ }^{12}$ The power rests in a Free Trade Commission (comprised of the trade ministers of each nation) that has limited meetings and issues statements. The actual work of administering the rules falls to advisory-only Working Groups ${ }^{113}$ established for each major subject matter area. The

NAFTA provides just what the title of the chapter suggests, the right to enter another Party's territory for purposes under the free trade agreement. See id. at art. 1603, Annex 1603 (allowing temporary entry for business visitors, traders and investors, intra-company transferees and professionals and spelling out in detail who qualifies for each group).

107. Id. at ch. 17.

108. North American Agreement on Labor Cooperation, Can.-Mex.-U.S., 39 I.L.M. 1499, Sept. 14, 1993, available at http:/www.dol.gov/ILAB/regs/naalc/main.htm [hereinafter NAALC]; North American Agreement on Environmental Cooperation, Can.-Mex.-U.S., 32 I.L.M. 1480, Sept. 14, 1993, available at http://www.cec.org/pubs_info_resources/law_treat_ agree/naaec/index.cfm [hereinafter NAAEC].

109. See NAAEC, supra note 111, at art. 3 (requiring each Party to "ensure that its laws and regulations provide for high levels of environmental protection and shall strive to continue to improve those laws and regulations").

110. NAFTA does have a chapter on Safeguards (Ch. 8), but not one on the anti-dumping and countervailing duty laws of the parties. This is true even though neither Canada nor Mexico wanted anti-dumping in the agreement. See D. Daniel Sokol, Order Without (Enforceable) Law: Why Countries Enter Into Non-Enforceable Competition Policy Chapters in Free Trade Agreements, 83 CHI.-KENT L. REV. 231, 278 (2008).

111. The United States refused to negotiate over the major agricultural barriers facing developing countries (production subsidies and tariff peaks on escalations) even in the hemispheric FTAA negotiations. It has never been on the table in any other U.S. FTA. See TRADE AND DEVELOPMENT REPORT 2007, supra note 26, at 59 (noting that developed countries fail to offer increased market access for agriculture goods because they would face hostile and well organized industry lobbying efforts against such a move).

112. See HUFBAUER \& SCHOTT, supra note 59, at 488.

113. This has changed somewhat in recent U.S. FTAs. The actual work of the agreements 
NAFTA Secretariat, with a mandate to oversee dispute settlement and assist the Working Groups, was actually split into three national sections. All of the later U.S. FTAs share this limited governance aspect. ${ }^{114}$

With respect to dispute settlement, the NAFTA model also tried to limit administration. Instead of establishing a central dispute settlement authority, the NAFTA parties created three separate dispute systems. ${ }^{15}$ These systems handle the major substantive issues covered by the agreement and controversial issues between the parties ${ }^{116}$ - Chapter 11B for Investor/State arbitration, ${ }^{117}$ Chapter 19 for bi-national review of Antidumping/Countervailing Duty determinations ${ }^{118}$ and Chapter 20 for resolving claims of violations of the FTA's obligations. ${ }^{119}$ The systems differ as to standing, ${ }^{120}$ type of legal review ${ }^{121}$ and the remedies/relief available. ${ }^{122}$ Tailoring each dispute settlement system to these subjects allowed the NAFTA parties to deal with particular problems

is done in sub-committees and working groups established for various subject matter area commitments. For an illustration, see CAFTA-DR, supra note 36, at art. 19.1(3) (giving the Free Trade Commission authority to delegate subcommittees and working groups power to modify the tariff phase-out schedule, common guidelines on tariffs and government procurement matters); see also U.S.-Peru FTA, supra note 38, at ch. 20.1.

114. Compare NAFTA, supra note 7, at ch. 20, with U.S.-Chile FTA, supra note 38, at ch. 21.

115. There are actually four systems for dispute settlement inside the original NAFTA text. The fourth one is a specialized dispute system for disputes in the financial sector. NAFTA, supra note 7, at ch. 19. NAFTA borrowed this idea from the U.S.-Canada FTA. It has not been used by the NAFTA parties.

In addition, there are dispute settlement mechanisms attached to both the NAALC and NAAEC. See NAALC, supra note 111, at arts. 27-41; NAAEC, supra note 111, at arts. 22-36.

116. In the U.S.-Canada FTA, Canada pushed for some solution to its belief that the United States was aggressive and unfair in its administration of its anti-dumping and countervailing duty laws. Rather than accept Canada's offer to harmonize legislation, the United States agreed to a bi-national review of final $\mathrm{AD}$ and CVD administrative determinations. Canada insisted that the system be carried over into NAFTA. See HUFBAUER \& SCHOTT, supra note 59, at 199200.

117. NAFTA, supra note 7, at ch. 11B.

118. Id. at ch. 19.

119. Id. at ch. 20 .

120. In Chapter 11, a NAFTA investor/investment is allowed to bring suit against the host state which has failed to follow its investment obligations under NAFTA. In Chapter 19, a NAFTA firm facing an adverse AD or CVD determination by another NAFTA party gets its government to invoke bi-national review. In Chapter 20, one NAFTA Party may bring a claim against another Party. For a thorough review of these issues, see C. O'Neal Taylor, Dispute Resolution as a Catalyst for Economic Integration and an Agent for Deepening Integration: NAFTA and MERCOSUR, 17 Nw. J. INT'L L. \& BUS. 850, 875-895 (1996/97).

121. In the Chapter 11 mechanism, an arbitral panel interprets Chapter $11 \mathrm{~A}$ obligations based upon a claim of violation. In the Chapter 19 mechanism, an arbitral tribunal reviews the $\mathrm{AD} / \mathrm{CVD}$ determination for whether it is consistent with the law of the administering country. In Chapter 20, the arbitral tribunal examines claims that there has been a nullification or impairment of benefits expected under NAFTA.

122. The Chapter 11 mechanism produces a binding arbitral award that can be enforced (for money damages) in court. In the Chapter 19 mechanism, the panel can affirm or reverse and remand the administrative determination. In the case of Chapter 20, the arbitral panel issues a report which can form the basis of a negotiated solution. See NAFTA, supra note 7, at chs. 11, 19, 20. 
caused by each: in the case of Chapter 11 , how to make investment rights credible for investors; for Chapter 19, how to counter the beliefs of Canada and Mexico and bias in the administration of U.S. unfair trade statutes; and for Chapter 20, how to allow for dispute resolution without compelling a solution. ${ }^{123}$ The later U.S. FTAs have retained the separate dispute settlement feature with one large exception: no FTA after NAFTA contains the Chapter 19 bi-national review process.

The WTO-plus model retains every major element of the NAFTA model. What has changed is the focus of the model. In all recent FTAs, the United States has tried to expand the gains made in the Uruguay Round and NAFTA in the areas of trade in services, IP rights ${ }^{124}$ and government procurement, or to include subjects that have resisted GATT/WTO discipline. ${ }^{125}$ These changes were dictated by the desire of the United States to use FTAs as "models for success" for the WTO system. ${ }^{126}$ The theory is that by including them in all regional agreements, the United States will be able to shift WTO Member States towards adopting these issues as a part of its future agenda. At the same time, other subjects have either been expanded or added to the WTO-plus model, notably Transparency/Anti-corruption, ${ }^{127}$ Electronic Commerce, ${ }^{128}$ and

123. Under NAFTA Article 2018, the parties to the dispute actually determine its outcome. Article 2018 provides: "On receipt of the final report of a panel, the disputing Parties shall agree on the resolution of the dispute, which normally shall conform with the determinations and recommendations of the panel, and shall notify their Sections of the Secretariat of any agreed resolution of any dispute." NAFTA, supra note 7, at art. 2018(1).

124. This had led to arguments that the U.S. approach with regard to some subjects, particularly intellectual property, is to seek more than the minimum standards negotiated for under the TRIPs Agreement in FTAs, producing an effect whereby: "[e]ach wave of bilateral free trade agreements contains more extensive intellectual property protections than the TRIPs Agreement ... [a]nd, each subsequent bilateral agreement creates a new minimum standard for intellectual property rights." Rahul Rajkumar, The Central American Free Trade Agreement: An End Run Around the Doha Declaration on Trips and Public Health, 15 AlB. L.J. SCI. \& TECH. 433, 448 (2005); see also PETER DRAHOS, UNITED KINGDOM COMM'N ON INTELLECTUAL Prop. RIGHTS, STUdY PAPER 8: DEVELOPING COUNTRIES AND INTERNATIONAL INTELleCTUAL PROPERTY STANDARD-SETTING 2 (2002, available at http://www.iprcommission.org/papers/ pdfs/study_papers/sp8_drahos_study.pdf.

125. Negotiations on investment rights were part of the Doha Agenda in 2001 but were withdrawn from the agenda by the WTO in the 2004 General Council after strong opposition at the 2003 Cancun Ministerial meeting. TRADE AND DEVELOPMENT REPORT 2007, supra note 26, at 61 .

126. The President's Trade Policy Agenda 2005, supra note 45, at 1.

127. The chapters on transparency and corruption provisions first appeared in the FTAs with Morocco. See U.S.-Morocco FTA, supra note 35, at ch. 18.1-18.4 (dealing with the traditional transparency issues of publishing all rules, regulations and the due process rights allowed citizens concerning notification, administrative proceedings and review and appeal of administrative or judicial proceedings), 18.5 (dealing with the anti-corruption obligation to adopt measures to criminalize corrupt payments). The other two FTAs negotiated and enacted at around the same time, the U.S.-Chile FTA and the U.S.-Australia FTA, have transparency obligations but no provision on anti-corruption. All of the recent FTAs (CAFTA-DR, the U.S.Peru FTA and the pending FTAs with Panama, Colombia and KORUS) have a slightly expanded section on anti-comuption. Compare U.S.-Morocco FTA, supra note 35, with U.S.- 


\section{Trade Capacity Building. ${ }^{129}$}

The reasons for the model's evolution and expansion are worth examining. In the case of two areas-investment and intellectual property rights - the model was changed to reflect experiences gained under NAFTA (investment) and to satisfy a powerful domestic interest group (intellectual property). Investment was always a crucial chapter for any U.S. FTA. The goal was two-fold - to encourage intra-regional investment flows by making them more secure, ${ }^{130}$ and to encourage tariff-jumping investment by nonmember country firms. ${ }^{131}$ The drafting of Chapter 11 itself was closely based

Peru FTA, supra note 38, at ch. 19B; U.S._Colombia FTA, supra note 20, at ch. 19B; U.S.Panama FTA, supra note 20 , at ch. 18B. The provision on anti-corruption in the KORUS FTA is closer to that in the U.S.-Morocco FTA. See KORUS, supra note 20, at Art. 21.6.

Transparency has always been a core principal of U.S. FTAs. See NAFTA, supra note 7, at art. 102(1) (transparency is listed as one of the principles of the agreement in Article 102, which sets out the objectives of NAFTA).

128. The chapters on electronic commerce were first added to the model in the agreements with Chile, Singapore, Australia and Morocco. See U.S.-Chile FTA, supra note 38, at ch. 15; U.S.-Singapore FTA, supra note 33, at ch. 14, U.S.-Australia FTA, supra note 38, at ch. 16; U.S.-Morocco FTA, supra note 35, at ch. 14.

129. Trade Capacity Building was first added to U.S. FTAs in the CAFTA-DR. See CAFTA-DR, supra note 36, at ch. 19 (entitled Administration of the Agreement and Trade Capacity Building). Similar provisions are in the U.S.-Peru FTA (ch. 20), U.S.- Panama FTA (ch. 19) and Colombia-U.S. FTA (ch. 20). See U.S.-Peru FTA, supra note 38, at ch. 20; U.S.Panama FTA, supra note 20, at ch. 19, Columbia-U.S. FTA, supra note 20, at ch. 20. Befitting South Korea's level of economic development, KORUS lacks any trade capacity building provisions.

The United States coordinates trade capacity building assistance through the U.S. Agency for International Development (USAID). Trade capacity building was aimed at assisting countries with accession to and implementation of WTO agreements, and to "build the physical, human, and institutional capacity to benefit more broadly from a rules-based trading system." GAO, FOREIGN ASSISTANCE: U.S. TRADE CAPACITY BUILDING EXTENSIVE BUT ITS EFFECTIVENESS HAS YET TO BE EVALUATED, GAO-05-150, at 3 (2005)[hereinafter GAO2005 REPORT], available at http://www.gao.gov/new.items/d05150.pdf. The connection to U.S. FTAs is the existence of a USAID/USTR interagency group formed to assist countries involved in free trade negotiations. Such efforts were made with regard to CAFTA. Id. at 3-4. Congress began to appropriate funds for trade capacity building programs in 2003 and 2004. Id. at 6-7. The largest proportion projects funded out of TCB were for trade facilitation-which includes, among other things, customs operation and administration and regional trade agreement capacity (defined as "to increase the ability of regional trade agreements and individual countries to facilitate trade and help potential regional trade agreement members.") $I d$. at 9 , Tbl. 1.

TCB Projects aimed at the Latin American FTA partners of the United States include a project in Central America to improve labor law compliance and a project in El Salvador to help Salvadoran food producers meet SPS standards regarding exports of fruits and vegetables. Id. at 13-14. The USAID approach to regional economic growth in Central America has been done by "taking stocks of each government's capabilities through diagnostic tools." Id. at 22.

130. This motivation was quite strong in the case of NAFTA given Mexico's history of strict regulation of investment and its embrace of the Calvo Doctrine. See generally HUFBAUER \& SCHOTT, supra note 59, at 201-02.

131. NAFTA achieves this by granting the Chapter $11 \mathrm{~A}$ rights to NAFTA investors/investments which allows non-party state firms to take advantage of them. See NAFTA, supra note 7, at art. 1101(1). 
on the U.S. model Bilateral Investment Treaty (BIT). ${ }^{132}$ Chapter $11 \mathrm{~A}$ on investment rights covers all of the same rights in the model BIT-national treatment, most-favored-nation treatment, minimum standard of treatment, expropriation and compensation, transfers, performance requirements, and hiring of Senior Management and Board of Directors. Given the experience of the U.S. under the BIT regime, which began in 1980, it was believed that the core obligations and their reach were well understood. NAFTA also borrowed the idea that the rights had to be made effective through neutral investor/state arbitration from the model BIT.

The WTO-plus model version of the investment chapter differs largely in its treatment of two of the core rights - minimum standard of treatment and expropriation/compensation. Aggrieved NAFTA investors have made heavy use of the Chapter 11B system to challenge government measures in all three NAFTA states. In almost every arbitration, claims were made based on the Minimum Standard of Treatment (Article 1105) and/or Expropriation (Article 1110). Expansive readings of both of these provisions by multiple arbitral tribunals ${ }^{133}$ inspired the NAFTA parties to issue interpretations of these provisions and the United States to alter its model BIT and future FTA investment chapters. ${ }^{134}$ With regard to both provisions, the governments were concerned by arbitral interpretations that limited government regulatory power. The revisions to the chapter, therefore, return power to the state and

132. The first model BIT was done in 1981, revised in 1994 and 2004 and is now undergoing a revision process started by the Obama Administration. See Joel C. Beauvais, Regulatory Expropriations Under NAFTA: Emerging Principles and Lingering Doubts, 10 N.Y.U. ENVTL L.J. 245, 252-53 (2002) (on the initial history); U.S. DEPARTMENT OF STATE, Bilateral Investment Treaties and Related Agreements, available at www.state.gov/e/eeb/ifd/bit (for a discussion of the 1994 revision and a copy of the 2004 Model BIT); Damon Vis-Dunbar, United States reviews its model bilateral investment treaty, INVESTMENT TREATY NEWS, June 5, 2009 , available at www.investmenttreatynews.org/cms/news/archive/2009/06/05/united-statesreviews-its-model-bilateral-investment-treaty.aspx (for a discussion of the goals behind the revision process).

133. The U.S. experience with investor-state arbitration has led to a significant revision of two major provisions of Chapter 11, Minimum Standard of Treatment (Art. 1105) and Expropriation (Art. 1110). For an analysis of how the results in Chapter 11 arbitrations altered the investment chapter model FTA, see Meg Kinnear \& Robin Hansen, The Influence of Chapter 11 in the BIT Landscape, 12 U.C. DAVIS INT'L L. \& POL'Y 101, 106-12 (2005); David A. Gantz, The Evolution of FTA Investment Provisions from NAFTA to the United States-Chile Free Trade Agreement, 10 AM. U. INT'L L. REV. 679 (2004).

134. Core provisions of Chapter 11 have been renegotiated and redrafted to clarify the meaning of concepts. Compare NAFTA, supra note 7, at arts. 1105, 1110, with U.S.-Peru FTA, supra note 38, at arts. 1105, 1110, Annexes 10-A, 10-B.

Investor-state arbitrations may also have been one of the reasons why some recent FTAs do not contain dispute settlement provisions in competition policy chapters. Sokol, supra note 113, at 274. There are not even any competition chapters in the recent CAFTA-DR, Morocco, or Bahrain FTAs. $1 d$. at 258 . According to Sokol, the United States is not the country pushing for such chapters. Id. at 258-59. "The United States' position may be best described as one that does not oppose competition policy chapters so long as the chapters remain non-binding and the PTA counter-party finds the inclusion of such a chapter to be important." Id. 
correspondingly limit the types of complaints that can be made under the system.

In the case of IP rights, the WTO-plus model has gone in the opposite direction. In response to a coordinated effort by industry, the United States Trade Representative (USTR), working in conjunction with industry and the IP advisory group for FTAs, has developed a "model FTA intellectual property text," which greatly expands the rights of IP holders ${ }^{135}$ beyond those required by the Trade-Related Intellectual Property Rights Agreement (TRIPs) of the WTO and NAFTA. The WTO-plus approach has been to go beyond the TRIPs/NAFTA emphasis on establishing minimum standards to imposing the intellectual property standards of a developed country. ${ }^{136}$ This has been achieved by limiting what is non-patentable, ${ }^{137}$ limiting government regulatory power ${ }^{138}$ and expanding the terms of the two major forms of IP rights-patent and copyright. ${ }^{139}$ FTA negotiations are judged as successful based on how

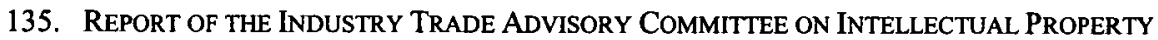
Rights (ITAC 15), The U.S.-PERu Trade Promotion Agreement (TPA): The INTEllectual ProPERTY Provisions 3 (2006), available at http://www.ustr.gov/assets/Trade_Agreements/ Bilateral/Peru_TPA/Reports/asset_upload_file473_8978.pdf [hereinafter PERU ITAC REPORT]. The exact same language is used in the ITAC-15 report for the pending U.S.-Panama FTA. See REPORT OF THE INDUSTRY TRADE ADVISORY COMMITTEE ON INTELLECTUAL PROPERTY RIGHTS (ITAC 15), The U.S.-Panama Trade Promotion Agreement (TPA): The Intellectual ProPERTY Provisions 3 (2007), available at http://ustr.gov/assets/Trade_Agreements/Bilateral/ Panama_FTA/Reports/asset_upload_file960_11234.pdf [hereinafter PANAMA ITAC REPORT].

136. The ITAC-15 report on the U.S.-Peru FTA states that "the fact that Peru found it in its own interest to significantly increase its leveis of IPR protection beyond that required by TRIPs is testament to the principle that high levels of protection benefits indigenous creators and inventors in the same manner as they do in developed countries." PERU ITAC REPORT, supra note 138 , at 5 .

137. In recent FTAs, U.S. partners have agreed to patent plants - an area that was left as one a country could consider non-patentable under TRIPs. See TRIPs, supra note 16, at art. 27(3)(b) (for the Trips exclusion) and compare with U.S.-Chile FTA, supra note 38, at art. 17.9 (providing for no exclusions). In the most recently adopted U.S. FTA with Penu the language on this issue has shifted again. See U.S.-Peru FTA, supra note 38, at art. 16.9 (2)(noting that 'Nothing in this chapter shall be construed to prevent a Party from excluding inventions from patentability as set out in Articles 27.2 and 27.3 of the TRIPS Agreement. Notwithstanding the foregoing, a Party that does not provide patent protection for plants by the date of entry into force of this Agreement shall undertake all reasonable efforts to make such patent protection available consistent with paragraph 1. .").

138. There has been a push by USTR to negotiate for a provision that would limit an FTA partner's ability to use compulsory licensing. See generally Rajkumar, supra note 127, at 44143, 474, for what TRIPs allows on the issue in recent FTAs.

139. In recent FTAs, the United States has pushed for the extension of the copyright term closer to the U.S. levels of 'life of the author' plus ninety-five years. It has only achieved that commitment with Oman. In the Peru and Panama agreements, the countries would only agree to what ITAC-15 calls the compromise seventy years. PERU ITAC REPORT, supra note 139, at 12. This goes well beyond the TRIPs minimum standard of fifty years. TRIPs, supra note 16, at art. 12.

With regard to patents, the protection offered would be extended if the issuance of the patent was subject to "unreasonable delay." U.S.-Peru FTA, supra note 38, at art. 16.9(6)(b). Since developing countries frequently take longer to issue patents than developed countries, this 
closely these extensions of IP rights come to U.S.-level standards. ${ }^{140}$ The WTO-plus IP chapter also emphasizes the importance of the enforcement obligations that FTA partner governments must undertake, ${ }^{141}$ and it greatly expands all of the types of remedies that must be made available. ${ }^{142}$ The overall effect of these IP additions is to limit the ability of FTA partners to make their own decisions about how to regulate intellectual property. ${ }^{143}$

The additions of the chapters on electronic commerce, transparency/anticorruption and trade capacity building have come in response to changes in the nature of trade (electronic commerce) and the shift in FTA partners (transparency/anti-corruption and trade capacity building). The largest proportion of recent FTAs has been entered into with developing countries. ${ }^{144}$ In order to aid these Latin American FTA partners, there has been a dedicated attempt to help improve governance and adherence to the rule of law through

provision will ensure a patent holder the full enjoyment of the patent term. In the U.S.-Peru FTA, "unreasonable delay" was the later of five years from filing or three years after an examination request. PERU ITAC REPORT, supra note 139, at 15 . In earlier FTAs, USTR had negotiated even better terms - the later of four years from filing or two years from examination. Id.

On patents, the FTAs also prohibit the marketing approval of generic drugs during the term of the drug patent. This provision effectively extends the life of the patent since competing companies must often wait until after the patent has run to produce a competing product. See generally Rajkumar, supra note 127, at 461-468 (discussing this issue in light of the CAFTADR FTA provisions).

140. Id. at 5 . The industry advisory committee urges USTR to obtain U.S. level standardas was done in several of the MEFTAI bilateral FTAs in future agreements.

141. Id. at 19. The United States wants its FTA partners to accept such standards because despite long term success at obtaining multilateral discipline through rulemaking, the United States still continues "to suffer billions of dollars in losses due to global piracy, counterfeiting and other infringements of rights provided in TRIPs (and in the various FTAs)-primarily due to ineffective enforcement by these trading partners." Id. at 18.

It is relatively easy for a developing country to legislate new IP rights protection. It is significantly more difficult to enforce those obligations. The implementation costs are significant and no FTA provides assistance regarding this issue. For a review of the implementation cost point, see J. MiCHAEL FINGER, THE DOHA AGENDA AND DEVELOPMENT: A VIEW From the URUGUAY Round 8-12 (Asian Development Bank 2002) (describing the implementation costs for IP rights obligations).

142. See U.S.-Peru FTA, supra note 38, at art.16.11 (11-17) (civil remedies), art. 16.11 (1825) (provisional remedies), art. 16.11 (26-28) (criminal remedies); PERU ITAC REPORT, supra note 139 , at $19-20$.

143. See Kenneth C. Shadlen, Globalisation, Power and Integration: The Political Economy of Regional and Bilateral Trade Agreements in the Americas, 44 J. DEV. STUDIES, 1, 11 (2008) (noting that the government limitations on the monopoly given by patents--"how easy or difficult it is to obtain a patent, how long the exclusive rights last, and the extent to which the holder can exclude others from freely using the idea"-are those developing countries use to get access to foreign innovations). It is in exactly these areas that the WTO-plus model IP chapter limits those regulatory powers by developing countries.

144. For example, in the case of the CAFTA-DR FTA all of the participating Central American countries, except for Costa Rica, were classified as lower income or lower middle income countries by the World Bank in 2005 (the year CAFTA-DR entered into force). See World Bank, World Development Report 2005: A Better Investment Climate for Everyone 254 255. 
the expansion of transparency obligations throughout the FTA text and in the adoption of anti-corruption provisions. ${ }^{145}$ The addition of trade capacity building to the WTO-plus model was also inspired by realizations that some FTA partners needed basic assistance to benefit from and adjust to the integration of free trade disciplines. ${ }^{146}$

\section{WHAT DOES IT MEAN TO DEVELOP AND USE A MODEL?}

Given the model-driven nature of U.S. regionalism, it is important to analyze the consequences of a model-based system for participating countries. What follows, therefore, is an analysis of the benefits and disadvantages inherent in the use of models. This analysis will begin with the effects of the model on the country producing it-the United States. The benefits to the United States will be examined in order of their importance. The paramount benefit of the use of the model, and one that is enhanced as long as it is used as a baseline and subjected to review and reworking, is that it allows the United States to focus on pushing its agenda on areas of major interest-trade in services, IP rights, investment and government procurement. The United States has succeeded in getting FTAs that cover issues or extend coverage on issues rejected by the multilateral system. Each FTA either covers the areas of greatest comparative advantage (trade in services, creation of intellectual property, and investment capacity), or is built around an attempt to achieve

145. By placing the transparency obligations in a separate chapter, the WTO-plus model attempts to underscore the connection between good governance and strong economics. Anticorruption is now also widely regarded as one of the biggest constraints facing developing countries as they pursue economic growth. The World Bank with its mission of eradicating poverty, for example, has made anti-corruption one of its key priorities-aiming its efforts at World Bank projects. At the same time the topic has attracted a great deal of attention on the issue of the link between corruption and development. For a summary of the issues involved see Omar Azfar, Young Lee \& Anand Swamy, The Consequences of Corruption, 573 ANNALS AM. ACAD. POL. \& Soc. SCI. 42, 50-53 (2001) (noting that the studies which have examined the link between corruption have found corruption has a negative impact on both the rate of investment and GDP growth of countries and that better institutional quality is linked to economic growth).

146. TCB Projects aimed at the Latin American FTA partners of the United States include: a project in Central America to improve labor law compliance and in El Salvador a project to help Salvadoran food producers meet SPS standards with regard to exports of fruits and vegetables. GAO 2005 REPORT, supra note 132, at 13-14. The USAID approach to regional economic growth in Central America has been "taking stocks of each government's capabilities through diagnostic tools." Id. at 22.

During negotiations for recent FTAs, particularly those in Central America and the Andean region, there has been a TCB working group led by USTR aimed at helping the countries deal with implementing the FTAs. Id. at 26 . USTR suggests trade capacity building initiatives, but actual projects are worked out later. Id.

In its most recent self-report to the WTO, the United States described FTAs as capable of contributing to the multilateral system by "introducing innovation and strengthened disciplines" and that TCB is a "critical part of the United States' strategy to help developing countries to implement and take advantage of market-opening and reform-oriented trade agreements." US/TPR, supra note 17, at 14, 22 . 
U.S.-level standards (IP rights ${ }^{147}$ and government procurement procedures), or both. The flexibility of the model also allows the United States to emphasize issues (such as transparency) or add new items (anti-corruption and capacity building) that may help the FTA work more effectively.

Another benefit of the use of the model relates to the efficiency and leverage capacity of negotiations themselves. The negotiations begin with the model being offered as the starting point and, on many issues, the ending point. This allows the negotiations for a complex agreement to be achieved within a few years and at a lower cost in human and financial resources. ${ }^{148}$ No major derogation is allowed by any developing country FTA partner. ${ }^{149}$ Since the United States does not have to start from scratch each time it negotiates a FTA, politically sensitive issues that have already been dealt with via inclusion in the model in a particular manner ${ }^{150}$ or exclusion ${ }^{151}$ from the model will remain under control. This, in turn, allows the USTR to focus U.S. leverage in negotiations on specific barriers or problems it has with an FTA partner or particular gains it hopes to make. For example, in the case of South Korea, the United States wanted to address long-standing concerns regarding Korean standards that limited U.S. market access. The United States wanted to open up the relatively closed automobile sector in that country. ${ }^{152}$ In the case of Panama, the United States was anxious to secure the best possible access to government procurement in order to benefit from the forthcoming major

147. See generally PERU ITAC REPORT, supra note 139, for a discussion of this issue.

148. One of the factors the USTR considers in evaluating FTA partners and its regionalism agenda is the issue of government constraints. GAO 2004 REPORT, supra note 46, at 10. According to the USTR, this issue of U.S. constraints deals primarily with its ability to staff negotiations. Id.

149. In the case of the U.S.-Australia FTA, the United States did agree that the investment chapter did not have to include the investor-state dispute settlement mechanism. Two other FTAs are also without this feature. In the case of the U.S.-Jordan FTA, that agreement was drafted before the model was set. The United States later closed the gap by entering into a BIT with Jordan. In the case of the U.S.-Bahrain FTA, the United States had already entered into a BIT with that country and so had access to invest disputes through that treaty. See U.S.Bahrain, Bilateral Investment Treaty, May 31, 2001, available at http://tcc.exprt.gov/ trade_Agreements/All_TradeAgreements/exp_002777.asp. The U.S.- Bahrain BIT went into force in 2001 while the U.S.-Bahrain FTA did not go into effect until 2006.

150. For example, despite the critiques aimed at the rules of origins used in the model FTA, the rules have not really been altered. Undoubtedly this is because of the effective pressure of industry groups seeking protection. See generally Hufbauer \& Schott, supra note 59, at 474475.

151. The obvious areas here are labor mobility and the unfair trade statutes.

152. Press Release, USTR, United States and the Republic of Korea Sign Landmark Free Trade Agreement (June 30, 2007), available at www.ustr.gov/Documents_Library/Press Releases/2007/June/United_States_the_Republic_of_Korea_Sign_Landmark_Free_Trade_Agre ement.html (noting that "KORUS FTA marks an unprecedented step in eliminating the tariffs and non-tariff barriers that U.S. automakers have identified as the impediments to their success in Korea's large market"); see also JEFFREY J. SCHOTT, PETERSON INST. FOR INT'L ECONOMICS, The KOREA-U.S. FreE TRADE AgreEMENT: A SUMMARY ASSESSMENT (2007), available at http://www.petersoninstitute.org/publications/pb/pb07-7.pdf. 
expansion of the Panama Canal. ${ }^{153}$

The United States also satisfies foreign policy goals with relatively little cost through the use of the model FTA. With its relatively open markets (in both trade in goods and services as well as government procurement) and its highly developed standards, the United States does not have to devote major resources or efforts to implementing its model FTA. However, the same cannot be said of any of its developing country FTA partners. ${ }^{154}$ Through the process of negotiating and assisting in implementation of the agreement with its partner, the United States solidifies its access to the existing and future governments of the partner. Even the shallow economic integration with the United States achieved by a free trade agreement makes it difficult, if not impossible, ${ }^{155}$ for an FTA partner to withdraw from the agreement. In turn, having common economic goals with the United States makes it harder for an FTA partner to ignore U.S. input or counsel with regard to domestic policymaking and at the multilateral level. ${ }^{156}$

Finally, there is the benefit of increased market access that comes from the use of a model FTA aimed at developing countries. Although an FTA deals with economic integration, the actual U.S. gains here are not significant given overall U.S. market size. The developing country partner, however, inevitably has higher tariffs, tariff-rate quotas and standards barriers that have made market access more difficult. Even if the developing country negotiated well, by protecting sensitive sectors of trade for as long as possible, U.S. market access will improve over the long run. The United States also obtains what USTR describes as a "level playing field" with a developing country FTA partner. Since most of the U.S. FTA partners receive some, and often high levels of, duty free access to the U.S. market, the FTA replaces such preferences with reciprocity. ${ }^{157}$

153. Press Release, USTR, U.S. and Panama Complete Trade Promotion Agreement Negotiations (Dec. 19, 2006), available at http://www.ustr.gov/Document_Library/Press_ Releases/2006/December/US_Panama_Complete_Trade_Promotion_Agreement_ Negotiations.html?ht $=$ (noting that the agreement would provide significant opportunities "to participate in the $\$ 5.25$ billion expansion plan" for the Canal).

154. Developing country FTA partners must devote significant resources to not only passing and implementing legislation but also to enforcement, particularly with regard to IP rights.

155. Every U.S. FTA provides the parties with the right to withdraw from the agreement within six months if it provides notice of withdrawal to the other parties. See NAFTA, supra note 7 , at art. 2205 . However, it would be quite costly for parties to withdraw, and that option has never been seriously considered by any FTA partner.

156. The United States has used the regionalism process to form alliances with developing countries that otherwise might belong to a WTO group adverse to its interests. See GAO 2004 Report, supra note 46, at $10,52$.

157. The Generalized System of Preferences is the largest U.S. preference program-it allows developing countries duty free access to the U.S. market GSP for thousands of products from over 100 designated, beneficiary countries. USTR, A GUIDE TO THE U.S. GENERALIZED SYSTEM OF PREFERENCES: GUIDEBOOK 3 (2006), available at http://www.ustr.gov/Trade Development/Preference_Programs/GSP/General_GSP_Program_Information/Section_Index. html (select "U.S. Generalized System of Preferences Guidebook"). The current version, which 
There are disadvantages to the United States from the use of the model. These can be categorized as those having primarily domestic consequences and those affecting U.S. multilateral interests. On the domestic side, the use of the model tightly links the U.S trade agenda to the political agenda of the Executive and his party. The power sharing over trade between Congress and the Executive has not been well managed since before NAFTA. ${ }^{158}$ There is a split between the parties ${ }^{159}$ over the shape and content of FTAs, as evidenced by the close votes on almost every recent FTA and the divide over how and when to extend Trade Promotion Authority (TPA). For example, in 2007, the Bush Administration was forced to accept a Bi-Partisan Trade Deal that required the USTR to alter the model and renegotiate all of the pending FTAs with Panama, Peru and South Korea to reflect demands by the Democrats. ${ }^{160}$ At one level, this reworking of the model signifies the reality of power sharing. At another level, it demonstrates that the Executive Branch can push its particular agenda into the model FTA so effectively that it loses touch with Congress.

Another disadvantage of the model with domestic and multilateral ramifications is that the use of a model freezes thinking. The United States has not revisited the basic premises of the NAFTA and the WTO-plus models over the last fifteen years. Is the model-most noted for pushing the U.S. agenda on deep integration issues - a good model? Undoubtedly, the use of the WTOplus model satisfies all U.S commercial goals and builds up some support for its agenda on deep integration issues. However, the focus on "competitive liberalization" has undercut irreplaceable U.S. leadership at the WTO, the better and more just forum for trade liberalization. Even with the efficiency gains achieved through the use of the model, this U.S. brand of "aggressive regionalism" has diverted attention and negotiating resources from multilateral negotiations. Moreover, the insistence on the model has also alienated countries that have resisted the U.S. approach.

has been enacted multiple times, expires at the end of 2008. The Caribbean Basin Initiative (CBI), 19 U.S.C. $\S 2702$ (2004), was first passed in 1983 and expanded in 2000 and 2002 in order to help countries in the area access the U.S. market. THE PRESIDENT's 2008 TRADE POLICY AgENDA, supra note 19, at 130. The Andean Trade Preference Act, Pub. L. No. 102182, 105 Stat. 1233 (1991), was passed to aid the Andean countries in their efforts to develop spur regional economic development to provide "economic alternatives to the illegal drug trade promote domestic development, and thereby solidify democratic institutions." THE PRESIDENT's 2008 TRADE POLICY AGENDA, supra note 19, at 129.

158. See generally Taylor, supra note 15 , at $15-23$, for a discussion of the reasons why it is difficult for Congress and the Executive Branch to share trade policy power.

159. See VAN GRASSTEK, supra note 47, at 7 (noting the difference between the Republicans and Democrats on FTAs and providing a complete breakdown of all trade votes illustrating the differences).

160. USTR, Peru and Panama FTA Changes (May 10, 2007), available at http://www.bilaterals.org/IMG/pdf/05_14_07.pdf. The deal required the changes to the three pending FTAs (Panama, Colombia, South Korea) with regard to labor rights and environmental issues-including placing all disputes on the obligations in those chapters into the regular dispute settlement mechanisms of each FTA —and with regard to IP rights. The IP rights provisions were notable for pulling back from the model IP text on issues related to pharmaceutical patents. 
A final disadvantage to the United States from the use of the model FTA comes from the very thing that makes it successful. The market size and wealth of the United States give it great leverage over its FTA partners. By insisting upon the model FTA, the U.S. approach is, and is seen as, an expression of power. This raises the issue of whether an imposed model of economic growth and development can be a successful "legal transplant." As noted by Alan Watson, legal transplants are a common and fertile source of legal development. ${ }^{161}$ However, one way to judge a "successful legal transplant" is to assess whether it continues to grow and develop in its new setting. ${ }^{162}$ The model FTA offers a "one size fits all" prescription (largely based on developed country standards) for countries at different stages of development and facing different constraints. If the transplanted legal FTA regime fails to assist with economic growth and development, not only will the FTA partner suffer, but the credibility of U.S.-led trade lawmaking will also be undermined.The benefits of the model FTA for developing countries are easier to delineate. The chance to obtain secure access to the large U.S. market and increased foreign direct investment (FDI) motivate developing countries to seek out or accept FTAs with the United States. Entering a reciprocal FTA frees a developing country from having to count on the more limited and uncertain world of preference programs. Moreover, the experience of Mexico under NAFTA suggests that increased market access will occur. ${ }^{163}$ As for investment, developing countries-at least those chosen as U.S. FTA partners-need capital infusions. It is the search for investment that has led many of these

161. Alan Watson, Legal Transplants: An Approach to Comparative Law 95 (Univ. of Ga. Press 1993) (1974).

162. Id. at 27.

163. Mexico does provide a model of what can happen to a developing country entering into an FTA with a major developed trading nation. Mexico has clearly seen an increase in trade and investment flows. Without NAFTA, Mexico's global exports would have been twenty-five percent lower and investment levels would have been forty percent lower. WORLD BANK, LESSONS FROM NAFTA FOR LATIN AMERICAN AND THE CARIBBEAN COUNTRIES 5 (2005), available at http://web.worldbank.org/WBSITE/EXTERNAL/COUNTRIES/LACEXT/0, contentMDK:20393778 pagePK:146736 piPK:146830 theSitePK:258554,00.html.

Before NAFTA, Mexico faced a trade deficit with the United States. Ten years after its entry into force it was running a trade surplus of $\$ 28.9$ billion. See Ranko Shakri Oliver, In the Twelve Years of NAFTA, the Treaty Gave to Me. . What, Exactly: An Assessment of the Economic, Social and Political Developments in Mexico Since 1994 and Their Impact on Mexican Immigration into the United States, 10 HARV. LATINO L. Rev. 53, 74 (2007). Mexico is also a more important trading partner of the United States-the second most important market for U.S. agriculture exports. Press Release, USTR, U.S.-Mexican Officials Meet to Discuss NAFTA (Jan. 11, 2008), available at http://www.ustr.gov/Document_Library/PressReleases/ 2008/January/U.S_Mexican_Officials_Meet_to_Discuss_NAFTA.html; see also TRADE AND DEVELOPMENT REPORT 2007, supra note 26 , at $\overline{70}$ (noting the increase in intraregional trade for Mexico as a result of NAFTA and the focus of those exports on the United States, so that Mexico is "the developing country with the highest concentration of exports to a single destination and the one with the largest increase in export opportunities from world import demand growth"). 
same countries to sign BITs. ${ }^{164}$ The chances for obtaining more FDI are measurably increased by a U.S. model FTA. ${ }^{165}$ U.S. investors have tended to follow its commitments under FTAs. It is true that to obtain the benefits, the developing country will have to participate, and potentially lose, in investment arbitrations. However, the revised investment chapter of the WTO-plus model does offer more clarity to a partner about its exposure and arguably more regulatory power.

Two other benefits from U.S. FTAs have been recognized. First, there is a "lock in" effect achieved by entering into and implementing FTAs. ${ }^{166}$ Second, by adopting the U.S. FTA, the developing country avoids isolation. No developing country facing the decision of whether to enter into a FTA with the United States acts without considering its position in relation to other countries. $^{167}$ All U.S. trading partners face competition from Asia, ${ }^{168}$ particularly the Latin American developing countries, and all have significant export relationships with the United States. ${ }^{169}$ These partners were put at a

164. See generally Andeas Lowenfeld, Investment Agreements and International Law, 42 COLUM. J. TRANSNAT'L L. 123, 126 (2003) (discussing the rationales for entering BITs); Jeswald W. Salacuse, Do Bits Really Work?: An Evaluation of Bilateral Investment Treaties and Their Grand Bargain, 46 HARV. INT'L L. J. 67, 77-111 (2005) (describing the bargain as "a promise of protection in return for the prospect of more capital in the future" and explaining that his study reveals that the bargain has worked).

165. If Mexico is used as a model, this appears to be the case. TRADE AND DEvelopMENT REPORT 2007, supra note 26, at 74 (investment levels almost quadrupled from the period before NAFTA (1990-94), when they averaged $\$ 5$ billion per year, to 2000-2004, when they averaged $\$ 19$ billion per year).

166. What countries try to "lock in" are trade reforms. See generally Robert E. Hudec, GATT's Influence on Regional Arrangements, in NEW DIMENSIONS IN REGIONAL INTEGRATION 151, 153 (Jaime de Melo \& Arvind Panagariya eds., Cambridge Univ. Press 1993). Hudec notes that: "Many of the developing countries responsible for the current wave of [regional arrangement] negotiations are often hoping to use [regional arrangement] negotiations to 'lock in' recently adopted trade policies-an objective that will be served by the greatest possible compliance with Article XXIV. Thus, this time around, we may well see a strong pressure for compliance with Article XXIV from the member developing countries themselves." Id.; see also WORLD BANK, DR/CAFTA: CHALLENGES AND OPPORTUNITIES FOR CENTRAL AMERICA 2932 (2005) [hereinafter DR-CAFTA REPORT] ("For Central American nations, locking many of the reforms of recent years with an FTA that is costly to violate should generate a credibility effect that could boost investment levels.").

167. Once the United States announced that it would negotiate an FTA with Mexico, there was a shift in the "status quo of trade relations" in the Americas. Other countries in the region, which were also heavily trade dependent on the United States, were faced with trade diversion. Many of these, such as Chile, Brazil, Argentina, Uruguay and Paraguay, approached the United States about free trade negotiations. The United States encouraged the last four to form a regional group. Richard E. Baldwin, A Domino Theory of Regionalism, in TRADING BLOCS 487-88 (MIT Press 1999); see also Shadlen, supra note 146, at 12-14.

168. See generally Enrique Dussel Peters, What Does China's Integration to the Global Economy Mean for Latin America? The Mexican Experience, in THE POLITICAL ECONOMY OF HEMISPHERIC INTEGRATION: RESPONDING TO GLOBALIZATION IN THE AMERICAS 58-81 (Diego Sanchez-Ancochea \& Kenneth C. Shadlen eds., Palgrave Macmillan 2008).

169. The United States is the major market for all of the recent Latin American FTA partners. See generally Shadlen, supra note 146, at 3-8. These countries send a greater 
disadvantage once Mexico entered into NAFTA. This drove Central American countries and the Dominican Republic to move ahead, even the less enthusiastic ones like Costa Rica. ${ }^{170}$ A similar concern faced Peru once Colombia began FTA negotiations. ${ }^{171}$ There is also evidence that developing countries agree to U.S. FTAs because the domestic interest groups (exporting firms operating in export-processing zones) are more influential than other groups regarding the shape and direction of trade. ${ }^{172}$

The disadvantages for the developing countries from the model FTA are significant and challenging. The developing country FTA partner lacks any leverage to get market access breakthroughs that would provide it with the greatest trade benefits. The U.S. refuses to negotiate on issues that would open up the agriculture market in FTAs. The model FTA, with its restrictive rules of origin, also keeps the textiles/clothing market more closed off than any other area of trade, except for agriculture. ${ }^{173}$ Moreover, if the rules of origin are complex enough, developing country firms face onerous compliance and record-keeping costs that can lead to under-utilization of market access benefits. If the developing country has negotiated tariff phase-outs well, it may be able to handle the inevitable adjustment that comes from a reciprocal FTA. If not, the developing country could face significant unemployment in sectors, such as agriculture, where it faces highly competitive ${ }^{174}$ U.S. import competition.

By adopting a U.S. model FTA, a developing country takes on not only legal rules ${ }^{175}$ but also substantial enforcement costs (in an area such as

proportion of their exports to the United States than to one another. Only $13.2 \%$ of Latin American exports were intra-regional. NATHALIE AMINIAN, K.C. FUNG \& FRANCIS NG, WORLD Bank, Policy Research Working Paper No. 4546, Integration of Markets vs. INTEGRATION BY AGREEMENTS (2008), available at http://www.wds.worldbank.org/ external/default/WDSContentServer/IW3P/IB/2008/03/04/000158349_20080304084358/

Rendered/PDF/wps4546.pdf.

170. See Shadlen, supra note 146, at 12-13. Costa Rica could not enact CAFTA-DR without a public referendum, which was held on October 7, 2007. The FTA was approved by the slimmest of margins (51.48\% in favor to $48.42 \%$ against). ICT Chamber Outlines Benefits of FTA for IT Industry, supra note 36. Costa Rica has had to request an extension of its March 2008 deadline in order to pass all of the implementing legislation needed to enact its FTA obligations. Costa Rica To Request Extension for Deadline To Enter CAFTA, supra note 36.

171. Shadlen, supra note 146, at 13.

172. Id. at 14 .

173. In recent FTAs with Latin American countries, these chapters are crucial. Since the textile sector is still relatively undisciplined, like agriculture, a U.S. FTA partner must try to negotiate provisions which will allow the greatest market access possible. The textile rules receive extended treatment in CAFTA-DR. In CAFTA-DR, the United States did agree to phase out all remaining multilateral quotas, but it obtained a special safeguard measure for textile imports. The parties also agreed to special customs cooperation procedures to aid in dealing with rule of origin issues. See CAFTA-DR, supra note 36, at arts. 3.22, 3.23 and 3.24.

174. U.S. agriculture is not only highly efficient but subsidized. A developing country facing such imports can be severely disadvantaged. See Oliver, supra note 166, at 76-89; DRCAFTA REPORT, supra note 169 , at 34 .

175. Even drafting the implementing legislation can be a complicated process for a developing country. For example, a key to dealing with U.S. FTA intellectual property obligations is drafting implementing legislation that covers all of the issues. The United States 
intellectual property). ${ }^{176}$ Scarce resources must be allocated to achieve FTA goals or the developing country will fail to derive the benefits of the agreement and face U.S. displeasure or disputes. Even more importantly, a developing country loses policy space when it accepts a U.S. FTA. ${ }^{177}$ Some of the possible government interventions that might aid a domestic industry, such as investment restrictions, government procurement set-asides, the limitation of IP rights and subsidizing exports, for example, are foreclosed by the model FTA. ${ }^{178}$ The final disadvantage of the U.S. model is its failure to confront its subjects. The status of the FTA partners as developing countries facing almost every type of resource constraint is largely unacknowledged. Transition periods for phasing in obligations that might assist with adjustment exist only in the trade in goods part of the FTA. ${ }^{179}$ In contrast, the model FTA has strictly limited phase-in for undertaking intellectual property rights obligations. In recent FTAs, these average only two to three years. ${ }^{180}$

There has been more of an effort to offer adjustment and implementation assistance through trade capacity building. The WTO-plus model FTA has provisions that establish a Trade Capacity Building (TCB) Committee for each agreement. ${ }^{181}$ There is no textual commitment, however, for financial resources

has discovered in dealing with FTA partners that even this first step is difficult. In its report on the U.S.-Panama FTA, the ITAC-15 advisory group noted that at least one FTA partner (Bahrain) had implemented non-compliant legislation and urged USTR to carefully "review all implementing legislation after it has been adopted to ensure that no FTA enters into force until compliance is achieved." PANAMA ITAC REPORT, supra note 138, at 3.

176. One of the reasons why developing country FTA partners have a difficult time with the U.S. model IP requirements is that enforcement costs can be steep.

177. See generally TRADE AND DEVELOPMENT REPORT 2007, supra note 26, at 57-65, for a complete analysis of all of the ways in which a developing country entering into a North-South FTA can lose policy space. See also Luis Abugattus \& Eva Paus, Policy Space for a CapabilityCentered Development Strategy for Latin America 113-43, in THE PolitiCAL ECONOMY OF HEMISPHERIC INTEGRATION, supra note 169 (Abugattus and Paus discuss not only the loss of policy space as a general issue but also particular ways this is experienced by the Latin American FTA partners); DANI RODRIK, THE NEW DEVELOPMENT ECONOMICS: WE SHALL EXPERIMENT, BUT HOW SHALL WE LEARN? 24-28, available at http://kgshome. harvard.edu/ drodrik/the $\% 20 \mathrm{New} \%$ Development $\% 20$ Economics.pdf.

178. See Dani Rodrik, How To Save Globalization from its Cheerleaders 13-15 (Sept. 2007) http:ksghome.harvard.edu/ drodrik/saving\%20globalization.pdf; Yong Shik Lee, Foreign Direct Investment and Regional Trade Liberalization: A Viable Answer for Economic Development, 39 J. WORLD TRADE 701, 706-11 (2005).

179. These are the tariff elimination phase-in periods and can extend for up to twenty years for sensitive products. However, under NAFTA, the parties frequently met to speed up tariff eliminations.

180. See U.S-Peru FTA, supra note 38, at Annex 16.1; U.S.-Panama FTA, supra note 20, at art 15.3.

181. The U.S. commitment to trade capacity building in the model FTAs is to create a TCB Committee for each agreement. The developing country partners are expected to periodically update and provide the Committee its national TCB strategy. In turn, the Committee will seek to: (1) prioritize projects at a national or regional level, or both; (2) invite donor institutions and other groups to assist in developing and implementing the projects; (3) assist with the implementation of projects; and (4) monitor and assess progress in implementing progress. The TCB Committee is required to meet at least twice a year during the transition period. 
to fund actual projects. The U.S. implementing legislation for the FTAs does not contain earmarked funding for TCB projects. Instead, the U.S. approach is to coordinate trade capacity building projects for FTA partners through its overall program. While adjustment projects aimed at major constraints (such as weak or non-existent physical infrastructure) have been funded and are underway, not all developing country FTA partners have yet benefited. ${ }^{182}$ Moreover, the United States has yet to monitor or assess existing projects for success and effectiveness. ${ }^{183}$

\section{AFTERWORD: A NEW MODEL?}

The abandonment of model-driven regionalism is difficult to imagine. The U.S. experience with free trade agreements (as well as with Bilateral Investment Treaties ${ }^{184}$ ) proved that the United States can largely dictate the terms of agreements with its chosen partners. ${ }^{185}$ Moreover the combined benefits from the use of the model - the ability to push the U.S. agenda on deep integration issues; efficiency gains in negotiations, locking in foreign policy

182. The TCB Chapter is notable for what it lacks. There is no textual commitment to financial assistance by the United States for these projects. The United States does provide such assistance through a general TCB program aimed at all trading partners. See Taylor, supra note 129. The fact that a developing country is an FTA partner, however, does not necessarily guarantee it more assistance or more timely assistance.

The United States provided \$7.1 billion in TCB assistance from 2001-2007. Latin America and the Caribbean area have received $\$ 1.9$ billion during that time frame, $\$ 554$ million of that figure in 2007. US/TPR, supra note 17, at 23. The Central American countries have received $\$ 650$ million in trade-related assistance since 2003 (which has focused on rural development and poverty reduction). See USTR, CAFTA POLICY BRIEF, CAFTA-DR-TRADE CAPACITY BUILDING ProGRAMS 1 (July 2007), http://www.ustr.gov/assets/Trade_Agreements/Regional/CAFTA/ Briefing_Book/asset_upload_file544_13195.pdf.

The largest recent contributions come from the Millennium Challenge Corporation (MCC) and focus on infrastructure development agricultural issues. These include a \$215 million dollar compact with Honduras to upgrade roads and promote agricultural development (June 2005); a $\$ 175$ million dollar compact with Nicaragua (July 2005) to improve highways to link producers to regional marketing, and a $\$ 461$ million compact with El Salvador to deal with promoting education, enterprise development, and transport infrastructure (November 2006). See Id.

Not all of the CAFTA countries have benefitted from the MCC program. Although they are eligible for assistance, Guatemala and the Dominican Republic have not yet satisfied the eligibility requirements for an MCC compact.

183. The current TCB program lacks systematic monitoring of TCB projects and has not developed performance indicators or compiled performance data about projects. GAO 2005 REPORT, supra note 132, at 29. Despite making substantial financial commitments to TCB programs, the U.S. agencies involved have not "specifically conducted program evaluations to assess the effectiveness of their trade capacity building efforts." Id. at 31 .

184. See Id. at 27 , \& supra note 135 for a detailed discussion of the model BIT and the plan of the Obama Administration to revise that model. See also United States Trade Representative, Notice of Bilateral Investment Treaty Program Review (July 14, 2009), available at http://www.ustr.gov/about-us/press-office/blog/notice-bilateral-investment-treaty-programreview.

185. Id. at 7, 9-11, 31-32. 
goals at low domestic costs and achieving increased access in FTA partner markets ${ }^{186}$ - are significant and unlikely to disappear. At the same time it is equally difficult to imagine that the model will remain unchanged. The confluence of three events will alter the use and potentially the content of the FTA model - the worldwide recession, the election of a new President and the shift in the makeup of Congress ${ }^{187}$ and the need for new trade promotion authority for future trade agreements.

Senator Obama campaigned against the approach of earlier administrations to free trade agreements - from NAFTA itself ${ }^{188}$ to the more recent and pending FTAs. ${ }^{189}$ President Obama must now shape a coherent approach to trade policy, one that will require a rebalancing of multilateralism and regionalism. It seems unlikely that the United States can continue to pursue regionalism as a top priority. In fact, trade policy must now contend for legislative space in a country deeply enmeshed in a financial crisis and a lingering recession. These events require the passage of major domestic legislation aimed at unraveling the financial crisis, stimulating the economy and gaining control over health care and energy policy. ${ }^{190}$ Early indications are that trade policy will not be in the forefront of legislative efforts. Nevertheless since most recent economic growth has come from exports, ${ }^{191}$ the Obama Administration has set out some basic approaches. The top priority will be to focus on multilateralism and the completion of the Doha Round. ${ }^{192}$ Meanwhile

186. Id. at 31-34.

187. In 2008 the Democrats regained true control of both the House and the Senate. With the election of a Democrat as President, it becomes more likely that FTA policy will be altered to reflect traditional Democrat concerns. See Id. at 37 \& supra notes 162-163.

188. See generally Gary Clyde Hufbauer \& Jeffrey J. Schott, NAFTA's Bad Rap, INT'L ECON. (Summer 2008), available at http://www.piie.com/publications/papers/hufbauerschott0808.pdf.

189. See Rossella Brevetti \& Amy Tsui, 2009 Outlook: Free Trade Agreements, 26 INT'L TRADE REP. 123 (Jan. 22, 2009)[hereinafter Free Trade Agreements].

190. See generally United States Trade Representative (USTR), The President's Trade Policy Agenda 2009 at 1-5 (Feb. 27, 2009), available at http://www.utsr.gov/ sites/default/files/uploads/reports/2009/asset_upload_file810_15401.pdf [hereinafter President's Trade Policy Agenda 2009]. See also Memorandum from the Trade Policy Study Group on a New Trade Policy for the United States to the President-Elect and the $111^{\text {th }}$ Congress (December 2008), available at http://www.iie.com/publications/papers/20081217 presidentmemo.pdf [hereinafter TPSG Memo]. The Trade Policy Study Group is a bi-partisan group of former U.S. trade officials (including 3 former USTR heads), lawyers and economists. The membership of the TPSG is listed at the end of the memorandum. Id. at 13-14.

Even six months into the new administration it is clear that trade policy is not at the forefront of policy-making. See Rossella Brevetti, Bilateral Agreements: Grassley Says Obama Sidetracked From Trade by Political Considerations, 26 INT'L TRADE REP. 854 (June 25, 2009)(Senator Grassley noted that the Obama Administration had stated in hearings on the U.S.-Panama FTA that the trade agenda is on hold until the administration determines how international trade fits within the domestic agenda.).

191. TPSG Memo, supra note 190 , at 9 (noting that "[o]ver the past year, increases in net exports have accounted for all U.S. growth.").

192. President's Trade Policy Agenda 2009, supra note 190, at 3. 
all aspects of the U.S. policy regarding regionalism will be reconsidered and will move slowly. ${ }^{193}$ NAFTA will not be reopened ${ }^{194}$ but will be expected to cover labor and environmental concerns in the same way as recent FTAs. The pending FTAs with Panama, Colombia and South Korea will be examined for effects on the U.S. and carefully worked through with Congress before any decision to move forward. ${ }^{195}$ Recent meetings with the leaders of these FTA partners have led the Obama Administration to believe that substantive issues of concern on each must be resolved before the FTAs can be sent to Congress for a vote. ${ }^{196}$ What has yet to be addressed, however, is the approach the administration plans for future trade agreements. This is hardly a surprise since planning for future trade endeavors (whether the completion of the Doha Round or future FTAs) will require the Obama Administration to seek trade promotion authority. ${ }^{197}$

As the Executive Branch rethinks regionalism some in Congress are pushing for a complete reworking of how trade policy is formed. This turn of events is also not surprising. Since the creation of the fast track process the President has discovered that seeking trade negotiating authority reopens the debate about the proper balance of power sharing over trade policy. ${ }^{198}$ The first legislation introduced on this topic by the $111^{\text {th }}$ Congress is the Trade Reform, Accountability, Development and Employment (TRADE) Act of 2009. ${ }^{199}$ The TRADE Act of 2009 would require: 1) the General Accountability Office to conduct a review of existing FTAs based on the current model, ${ }^{200} 2$ ) the use of

193. Id. at 4 .

194. See Kirk: NAFTA Problems Can be Fixed Without Reopening the Trade Agreement, 27 INSIDE U.S. TRADE No. 16 (April 24, 2009); Rossella Brevetti, Kirk Says USTR to Review Colombia FTA, Reopening of NAFTA May Not be Necessary, 26 INT'L TRADE REP. 534 (Apr. 23, 2009).

195. President's Trade Policy Agenda 2009, supra note 190, at 4; See also Amy Tsui, USTR Nominee Kirk Tells Senate Finance Enforcement Top Priority of Administration, 26 INT'L TRADE Rep. 341 (Mar. 12, 2009); See also Rossella Brevetti, Bilateral Agreements: Obama Says Administration Developing Action Plan for FTAs, 26 INT'L TRADE REP. 636 (May 14, 2009).

196. See Rossella Brevetti \& Heather M. Rothman, Bilateral Agreements: President Obama to Lay Out New Framework for Trade, Panel Told at Panama FTA Hearing, 26 INT'L TRADE REP. 73 (May 28, 2009); Obama, Uribe Cover Pending FTA As Part Of Range Of Issues, 27 INSIDE U.S. TRADE No. 26 (July 3, 2009); Obama shows Tentative support for Korea FTA Afier Summit with Lee, 27 INSIDE U.S. TRADE No. 24 (June 19, 2009).

197. See President's Trade Policy Agenda 2009, supra note 190, at 1 (noting that one of the tools the President will need to address the economic crisis is trade promotion authority). President Obama has taken the position that trade promotion authority is something it will ask for "after engaging in extensive consultation with Congress to establish the proper constraints on that authority and after we have assessed our priorities and made clear to this body and the American people what we intend to do with it.") Id.

198. See C. O'Neal Taylor, supra note 120, at 22-55.

199. H.R. 3012, $111^{\text {th }}$ Cong., $1^{\text {st }}$ Sess. (June 24, 2009), available at http://thomas.loc.gov/ cgi-bin/query/F?c111:1:/temp/ c111aGk89A:e2989:.

200. Id. at Sec. 3. 
specific FTA provisions in fifteen different subject matter areas, ${ }^{201}$ and 3) the submission by the President of a plan to renegotiate existing FTAs in accordance with the act's specifications. ${ }^{202}$ The TRADE Act of 2009 would further shift power towards Congress by having that body set the readiness criteria for FTA partners, ${ }^{203}$ mandate the negotiating objectives for agreements, ${ }^{204}$ and require its approval of any FTA before it is signed by the President. ${ }^{205}$ Whether this legislation ever proceeds to a vote, ${ }^{206}$ its introduction suggests that the Obama Administration must carefully calibrate its approach on trade policy to bring Congress along.

At least two paths appear open to the Obama Administration. First, it can focus on multilateralism and limit attempts at regionalism. This would mean completing the Doha Round and securing passage only of the pending FTAs which have critical Congressional support. It would also mean the indefinite postponement of any future FTAs until there is greater consensus on the proper goals of regionalism. ${ }^{207}$ Second, the Obama Administration could work out how to accommodate both a commitment to true multilateralism with regionalism. Such an approach would also require taking a leadership role in the completion of the Doha Round ${ }^{208}$ and on most, if not all, of the pending

\footnotetext{
201. Id. at Sec. 4.

202. Id. at Sec. 5.

203. Id. at Sec. 7(1).

204. Id. at Sec. 7(4).

205. Id. at Sec. 7(7).
}

206. See Kiera McCaffrey, 100 House Dems Want New Trade Rules, THE Hill, June 24, 2009, available at http://thehill.com/leading-the-news/100-house-dems-want-new-trade-rules2009-06-24.html (noting that H.R. 3012 had on that day 100 co-sponsors while similar legislation introduced in 2008 attracted only 74 co-sponsors and indicating that the larger number for this version "reflects both the larger Democratic majority in the House and increasing skepticism about trade amid a global recession."). See also Rossella Brevetti, Trade Policy: Over 100 House Members Endorse Reform Bill charting New Direction on Trade, 26 INT'L TRADE REP. 876 (July 2, 2009)(describing the outlines of the TRADE Act of 2009).

207. See Paul Blustein, REIMAgINING Global TRADE, available at http://www.brookings.edu/reports/2008/ /media/Files/rc/reports/2008/10_global_economic_ top_ten/200810_trade.pdf. [hereinafter Blustein]. This article is part of a series done by the Brookings Institute entitled “The Top 10 Global Economic Challenges Facing America's $44^{\text {th }}$ President." In this chapter Blustein suggests that one way to revitalize trade policy would be for the President to "propose a moratorium on bilateral trade agreements, a step that would be welcomed by many poor countries, which fear being marginalized in an increasingly splintered world of trade." Id. at 14.

208. See UNITED STATES TRADE REPRESENTATIVE, Remarks by Ambassador Ron Kirk at the U.S. Chamber of Commerce, Next Steps on the Trade Agenda, May 18, 2009, available at http://www.ustr.gov/about-us/press-office/speeches/transcripts/2009/may/remarks-ambassadorron-kirk-us-chamber-commerce (Amb. Kirk notes that the U.S. "economy is in trouble, and the steep decline in global trade is only exacerbating the crisis here and abroad" and states that he and President Obama are "committed to a successful conclusion of the Doha Round, to revive confidence in global trade and lay the framework for the robust trading system of tomorrow." Amb. Kirk notes that part of that effort involved his meeting with meeting with representatives of more than half the membership of the WTO)[hereinafter Kirk Speech]. The United States reaffirmed its goal of leading the Doha Round revival by signing on to the G-8 Summit 
FTAs. $^{209}$ What would differ from the other path is that the administration would have to develop a new paradigm for future regionalism. Following this path would require the U.S. to answer several questions. Should the United States continue to push its ideal trade agenda through FTAs? It might be possible for the U.S. to force its agenda on a WTO worried about losing relevance ${ }^{210}$ and on struggling developing countries suffering in the current recession. $^{211}$ Or should the United States use FTAs to grow U.S. export markets and see them largely as complements to multilateralism? Adopting this set of goals would require the U.S. to abandon several aspects of the existing model FTA ${ }^{212}$ as well as its factors and method for choosing FTA partners. ${ }^{213}$

commitment to complete the Doha Round by 2010. See George Parker, Guy Dinmore \& Alan Beattie, Leaders Seek to Agree Trade Deal by 2010 (July 10, 2009), available at http://www.ft.com/cms/s/0/6a804150-6ce6-11 de-af56-00144feabdc0.html.

209. See Kirk Speech, supra note 208 (describing the efforts USTR is making to determine the ways in which each pending FTA must be studied and improved to move forward while also detailing the benefits to the U.S. from each).

210. See Blustein, supra note 207, at 14 (noting the importance of "breathing life into the Doha Round" since the woes of the struggling talks in 2008 had raised "profound concerns about the World Trade Organization's ability to continue as the main rule writer for global trade."); see also WORLD TRADE ORGANIZATION, Introductory Remarks by Director General Pascal Lamy, Global Crisis Requires Global Solutions (July 13, 2009), available at http://www.wto.org/english/news_e/news09_e/tpr_13jul09_e.htm. Introducing a report on recent trade and trade-related developments associated with the financial and economic crisis Director General Lamy noted that it is the WTO's multilateral trade rules that provide a "valuable insurance policy against protectionism spiraling out of control" but also warning that "as long as we continue failing to pay the premiums on that insurance policy, by delaying the conclusion of the Doha Round, we are leaving ourselves no room for complacency about the future." Id. See also TPSG Memo, supra note 190, at 10-11 on the importance of completing the Doha Round and on needed improvements to the WTO).

211. See Daniel Pruzin, Balance of Trade: WTO Chief Sees Drop in Global Trade for 2009, Down 10\%, 26 INT'L TRADE REP. 910 (July 9, 2009)(noting WTO Director General Lamy's reporting of the overall drop off in trade for both developed and developing countries and his statement that while the volumes of lost trade are higher for the developed countries the impact is more significant for the developing countries because they are "more dependent on trade and as a consequence are harder hit by the current crisis." Lamy is also quoted as explaining that developing countries are also exposed because "they do not have the kind of social safety nets that will help amortize the impact of the crisis.").

It is this vulnerability to the world-wide recession and its effects that would make a developing country accept a U.S.-dictated FTA in order to have access to the U.S. market for goods that could otherwise face protectionism. Many developing countries thought that bargain was a good one even before the current crisis. See supra notes 35-38 (outlining the benefits developing countries receive from the current WTO-plus model FTA).

212. For example, there would be little reason to push developing countries currently struggling to accept U.S.-level protections for intellectual property rights. See supra notes 2830 for a discussion of the ratcheting up of U.S. demands on IPRs in the recent FTAs and the consequences for developing countries.

213. The Obama Administration would undoubtedly have to confer more closely with Congress on which countries to approach for a possible FTA. It is difficult to imagine that given the recession and the need to achieve a Doha Round break through to ease the trade crisis facing the United States that USTR will have the freedom to create and employ a list of factors like that developed by the Bush Administration. See supra notes 9-11 for a discussion of the current process. 
Instead the United States would have to devise a more flexible, less U.S.dictated model that would allow for FTAs with major developed country trading partners (such as the EC or Japan ${ }^{214}$ ) or the emerging developing country powers (the BRIC countries ${ }^{215}$ ) or for completing stalled regional efforts such as the FTAA or initiatives in Asia. ${ }^{216}$ Other options for revising the model would be for the U.S. to add other subject matter areas such as infrastructure services, energy and the environment. ${ }^{217}$

Proceeding on this path would mean that the United States would eliminate most of the disadvantages of using the current model - the disconnect between the President and Congress over the goals of trade policy, the frozen thinking and the use of FTAs as tools of power. ${ }^{218}$ No new model of this type could be achieved without closer cooperation between the Executive Branch and Congress and without educating the public on the gains from such agreements while assisting it with the effects. ${ }^{219}$ All of these efforts would

214. See TPSG Memo, supra note 190, at 11-12.

215. The BRIC countries are Brazil, Russia, India and China. See TPSG Memo, supra note 190 , at 12 suggesting that future FTA efforts might involve three of the BRIC countries - Brazil, China and India.

216. Id. at 11. The Trade Policy Study Group suggests these goals as a part of its endorsement of the idea of "harmonizing existing pacts in the Western Hemisphere and across the Asia-Pacific region." Id. See supra notes 4-6 and 8 for a discussion of the FTAA and the fact that it was ultimately suspended because of the unwillingness of major participants such as Brazil and Argentina to accept the terms of U.S.-model driven FTAA. See Kirk Speech, supra note 208, for a discussion of Amb. Kirk's interest in taking "a robust look at US trade policy towards Asia." and promising that "[e]ven more effective engagement with Asia will be a key component of the Obama administration's outlook on trade."

217. Id. at 12. This also would appear to fit with the Obama Administration's commitment to "make trade an important tool for achieving progress on national energy and environmental goals." President's Trade Policy Agenda 2009, supra note 190, at 3.

218. See supra notes 34-35 for a discussion of the disadvantages incurred by the use of the current WTO-plus model.

219. This issue is crucial because Congress reacts directly to the views of the public on trade. One of the legacies of the debate over NAFTA has been the belief that trade agreements cost U.S. jobs. The Obama Administration recognized this by insisting that a crucial part of its trade policy be accompanied by an expansion of the Trade Adjustment Assistance (TAA) - the program aimed at aiding workers displaced by the implementation of trade agreements. President's Trade Policy Agenda 2009, supra note 190, at 3; Kirk Speech, supra note 208. Amb Kirk stated that "[i]n the first weeks of this administration, President Obama also acknowledged some of the realities of trade and supported Congress's efforts to dramatically expand access to Trade Adjustment Assistance." Id.

For a thorough description of the TAA program and its many limits before this recent expansion see William J. Mateikis, The Fair Track to Expanded Free Trade: Making TAA Benefits More Accessible to American Workers, 30 HOUS. J. INT'L L. 1 (2007). See also TPSG Memo, supra note 190, at 7-9 for a discussion of how the TAA program must be altered to offer true access to benefits and play a useful role in a sound U.S. trade policy. It is not enough to assist U.S. workers impacted by trade agreements. The administration is unlikely to develop a successful trade policy without conveying the message that the U.S. stands to gain much from the continued expansion of trade. The Obama Administration is attempting such an effort. See Kirk Speech, supra note 208 (Amb. Kirk noted that one quarter of a million U.S. firms export goods and that almost all of them are small and medium-sized firms "who particularly need our help 
require a thorough revisiting of U.S. views on the strategic as well as economic goals of trade policy. Crafting a new FTA model with a development focus, however, might achieve both types of goals. ${ }^{220}$ When it chooses to negotiate with a developing country partner the U.S. could expand its Trade Capacity Building $^{221}$ efforts to ease and assist with the negotiation as well as the implementation burdens imposed by an FTA. Should it take such an approach the United States would address one of the major disadvantages currently faced by its developing country FTA partners. ${ }^{222}$ Adapting the FTA model into a development tool would also signal the existence of a true U.S. commitment to the advancement of the interests of developing countries. At the current time it is impossible to measure the value of such a commitment to the world trading system and U.S. credibility. ${ }^{223}$

accessing global markets" and that "[e]xporting firms tend to increase employment more rapidly, have higher productivity, and can pay as much as 13 to 18 percent more than the national average.").

220. See TPSG Memo, supra note 190, at 1 ("Trade is so central to most other countries, especially poor countries that depend on it for development, that trade policy is tantamount to foreign policy for many of them.).

221. See id. at 31,39-40 for a discussion of what the U.S. currently does and fails to do with Trade Capacity Building (TCB).

222. In order to improve how it does TCB, the United States needs to think through what role it wants for the program. A systematic diagnosis of the adjustment issues faced by developing country partners (available from work conducted by the World Bank) would be a starting point. Then, if the goal is to demonstrate how the FTA can complement development, TCB projects would need to be driven by the national development strategy of the developing country partner.

223. Ambassador Kirk expresses it best when he notes that "as the current economic crisis has shown us, in the interconnected global community in which we live-we sail or sink together." Kirk Speech, supra note 208. 
